ORIGINAL ARTICLE

\title{
Comparison of the genetic determinism of two key phenological traits, flowering and maturity dates, in three Prunus species: peach, apricot and sweet cherry
}

\author{
E Dirlewanger ${ }^{1}$, J Quero-García ${ }^{1}$, L Le Dantec ${ }^{1}$, P Lambert $^{2}$, D Ruiz ${ }^{2}$, L Dondini ${ }^{3}$, E Illa ${ }^{4}$, B Quilot-Turion ${ }^{2}$, \\ J-M Audergon ${ }^{2}$, S Tartarini ${ }^{3}$, P Letourmy ${ }^{5}$ and P Arús ${ }^{4}$
}

The present study investigates the genetic determinism of flowering and maturity dates, two traits highly affected by global climate change. Flowering and maturity dates were evaluated on five progenies from three Prunus species, peach, apricot and sweet cherry, during 3-8 years. Quantitative trait locus (QTL) detection was performed separately for each year and also by integrating data from all years together. High heritability estimates were obtained for flowering and maturity dates. Several QTLs for flowering and maturity dates were highly stable, detected each year of evaluation, suggesting that they were not affected by climatic variations. For flowering date, major QTLs were detected on linkage groups (LG) 4 for apricot and sweet cherry and on LG6 for peach. QTLs were identified on LG2, LG3, LG4 and LG7 for the three species. For maturity date, a major QTL was detected on LG4 in the three species. Using the peach genome sequence data, candidate genes underlying the major QTLs on LG4 and LG6 were investigated and key genes were identified. Our results provide a basis for the identification of genes involved in flowering and maturity dates that could be used to develop cultivar ideotypes adapted to future climatic conditions. Heredity (2012) 109, 280-292; doi:10.1038/hdy.2012.38; published online 25 July 2012

Keywords: Prunus; phenology; flowering date; maturity date; QTL analyses; candidate gene

\section{INTRODUCTION}

In the context of global climate change, flowering phenology of deciduous tree species is crucial as it may affect their productivity. In fruit tree orchards, flowering phenology has an indirect influence on spring frost damage, pollination, dormancy and maturity. Even though in a warming scenario, the current risk of frost damage might remain a preoccupation for growers subsequently to advanced flowering time and more irregularities of temperature conditions. Moreover, new risks are emerging as disruptions in floral phenology synchronization, which may disturb pollination for varieties that necessitate cross pollination. In addition, marked changes in the order of flowering time within a varietal range or between adjacent cropping areas may modify the orders of fruit maturity time and consequently disturb commercial specificities.

The Prunus genus, within the Rosaceae family, is characterized by species that produce drupes as fruit, and can be divided into three major subgenera: Amygdalus (peach (Prunus persica (L.) Batsch) and almond (Prunus dulcis Mill.)), Prunophora (apricot (Prunus armeniaca L.)), Cerasus (sweet cherry (Prunus avium L.) and sour cherry (Prunus cerasus L.)). All these species are grown in climates with well-differentiated seasons where they have adapted to survive to low winter temperatures and summer drought. In Prunus, as in most woody perennials, the physiology and biochemistry of the flowering process is poorly understood, although some investigations have been directed towards the elucidation of the genetic control of flowering time. Variations in flowering time occur due to the differences in the chilling and heat requirements before flowering. However, studies conducted on apricot (Ruiz et al., 2007), sweet cherry (Alburquerque et al., 2008) and peach (Okie and Blackburn, 2008) suggested that in Prunus, chilling requirements have much stronger effects on flowering time than heat requirements. Genotypes with low chilling requirements bloom early in cold regions and are susceptible to late frost damage. On the other hand, genotypes with high chilling requirements could suffer inadequate chilling in warm regions or years, resulting in irregular floral and leaf bud breaks, and thus poor fruit set, which is potentially problematic with the current global warming trend. In temperate fruit tree species, early ripening cultivars are often preferred because of better market prices for their fruits.

Except for almond where a major gene was identified, denoted $L b$, with late blooming being dominant over early blooming date (Ballester et al., 2001), flowering date is considered to be quantitatively inherited in most fruit tree species. Indeed, Quantitative trait loci (QTLs) for flowering date were detected in numerous genomic regions in Prunus. Using the terminology of the $\mathrm{T} \times \mathrm{E}$ reference map (almond cv. Texas $\times$ peach cv. Earlygold map), QTLs were detected in the $\mathrm{T} \times \mathrm{E} \mathrm{F}_{2}$ population on four linkage groups (LG), LG1, LG4, LG6

1INRA, UR419, Unité de Recherches sur les Espèces Fruitières (UREF), Centre de Bordeaux, Villenave d'Ornon, France; 2INRA, Unité de Génétique et d'Amélioration des Fruits et Légumes (UGAFL), BP 94, Montfavet, France; ${ }^{3}$ DCA, Department of Fruit Tree and Woody Plant Science, University of Bologna, Bologna, Italy; ${ }^{4}$ IRTA, Centre de Recerca en Agrigenòmica CSIC-IRTA-UAB-UB, Campus UAB, Bellaterra (Cerdanyola del Vallès), Barcelona, Spain and ${ }^{5}$ CIRAD, UR Systèmes de Culture annuels, Montpellier Cédex 5 , France

Correspondence: Dr E Dirlewanger, INRA, UR419, Unité de Recherches sur les Espèces Fruitières (UREF), Centre de Bordeaux, F-33140 Villenave d'Ornon, France. E-mail: dirlewan@bordeaux.inra.fr

Received 9 December 2011; revised 25 May 2012; accepted 18 June 2012; published online 25 July 2012 
and LG7 (Joobeur, 1998). In peach, QTLs have been detected over four different populations on all LGs except LG8 (Dirlewanger et al., 1999; Verde et al., 2002; Quilot et al., 2004; Fan et al., 2010). In almond, the major gene $L b$ was first mapped on LG4 using the progeny from a cross between ' $\mathrm{D}-3-5$ ', a $\mathrm{Lb} / \mathrm{lb}$ heterozygous genotype, and 'Bertina' (Ballester et al., 2001). The same location of the $L b$ gene was then determined in the $\mathrm{F}_{1}$ almond progeny 'R1000' × 'Desmayo Largueta' (Sánchez-Pérez et al., 2007). A candidate gene (CG) approach associated only 2 of 10 CGs, homologous to LEAFY and MADS-box genes in Arabidopsis, with two QTLs in almond (Silva et al., 2005), suggesting that direct application of the knowledge of the genetic control of the flowering time of annual plants to perennial tree species may be more complicated than expected. In apricot, a single QTL located in the first third of the LG5 of 'Z506-07', a $F_{1}$ selection derived from a cross between 'Orange Red' $\times$ 'Currot', explained most of the phenotypic variation (Campoy et al., 2011). In sour cherry, in a population issued from the cross 'Rheinische Schattenmorelle' (RS) $\times$ 'Erdi Botermo' (EB), a QTL for flowering date was mapped to the EB LG1 (Wang et al., 2000).

The decomposition of flowering dates into chilling and heat requirements has recently been studied in peach and in apricot. In peach one major QTL for chilling requirements was identified on LG1, co-localizing with a QTL for flowering date, and overlapping the evergrowing region (Fan et al., 2010). Another QTL mapped on LG7 and co-localized also with a QTL for flowering date. These colocalizations suggested that a unique temperature sensor regulates both traits. In apricot, chilling requirements and bud break were analyzed in an $\mathrm{F}_{1}$ population 'A.1740' $\times$ 'Perfection' and QTLs were detected in all LGs except LG3 and LG4 (Olukolu et al., 2009).

Maturity date was studied in peach and almond. For peach, QTLs mapped to LG2 and LG6 (Verde et al., 2002), LG2, LG3 and LG4 (Quilot et al., 2004), and LG1, LG4 and LG6 (Eduardo et al., 2011). The most significant QTLs were detected on LG4 and LG6. In one of the peach populations studied, a QTL detected on LG4 could be considered as a major gene, as the percentage of explained variance was close to $98 \%$ (Eduardo et al., 2011). In almond, QTLs with low effect were mapped to LG4 and LG5 (Sánchez-Pérez et al., 2007).

The objective of this study was to identify QTLs associated with flowering and maturity dates using five Prunus mapping populations from three species, two of peach, two of apricot and one of sweet cherry. This study aims to (i) investigate the stability of QTLs for flowering and maturity dates from year to year and to (ii) compare the genomic regions involved in these three Prunus species. QTLs presented here on sweet cherry are the first reported in this species. Finally, we proposed putative CGs underlying two major QTLs by in silico mapping using the peach genome sequence annotation. The practical objective will be to provide information on the genetic basis of these traits and to facilitate the selection of cultivars adapted to the climatic conditions of a specific region.

\section{MATERIALS AND METHODS}

\section{Plant material}

Five populations from three Prunus species were used. One of them is an intraspecific $F_{2}$ peach population derived from a cross between 'Ferjalou Jalousia' and 'Fantasia', $(\mathrm{J} \times \mathrm{F})$, including 208 individuals, previously used for QTL mapping of peach fruit quality (Dirlewanger $e t$ al., 2006). The second one is an interspecific advanced backcross progeny (Quilot et al., 2004) from a cross between a peach cultivar 'Summergrand' and P. davidiana clone P1908. One of the resulting $F_{1}$ hybrids was backcrossed to 'Summergrand' to obtain a $\mathrm{BC}_{1}$ progeny. A mixture of pollen from $\mathrm{BC}_{1}$ individuals was used to pollinate a white-fleshed nectarine ('Zephyr') to generate this mapping population, named $\mathrm{BC}_{2}(n=156)$. In this study, we only considered markers that distinguish $P$. davidiana and 'Summergrand' genomes. Two intraspecific apricot progenies were analyzed: one derived from a cross between the American cultivar 'Goldrich' and the Spanish cultivar 'Moniquí, called $\mathrm{G} \times \mathrm{M}$, which includes 178 individuals. The other apricot population, consisting of $118 \mathrm{~F}_{1}$ individuals, derives from a cross between 'Lito' and 'BO81604311', named L $\times$ B (Dondini et al., 2007). The sweet cherry progeny, called $\mathrm{R} \times \mathrm{L}$, is issued from a cross between a German cultivar, 'Regina' and an American cultivar, 'Lapins', and includes 124 individuals. The $\mathrm{J} \times \mathrm{F}, \mathrm{R} \times \mathrm{L}, \mathrm{BC}_{2}$ and $\mathrm{G} \times \mathrm{M}$ progenies were cultivated in France, in Toulenne located at $30 \mathrm{~km}$ south-west from Bordeaux for the two first ones and near Avignon for the two last ones; and the $\mathrm{L} \times \mathrm{B}$ progeny was cultivated in Italy, near Bologna.

\section{Evaluation of flowering and maturity dates}

Flowering date was evaluated for 8 to 3 years depending on the mapping population, in all but the apricot $\mathrm{L} \times \mathrm{B}$ progeny, that was not evaluated for flowering date because the variability for this trait was very limited (8 years on $\mathrm{J} \times \mathrm{F}, 7$ on $\mathrm{BC}_{2}, 4$ on $\mathrm{R} \times \mathrm{L}$ and 3 on $\mathrm{G} \times \mathrm{M}$ ).

The evaluation of the flowering date was performed according to the procedure usually used in each site. At INRA Avignon, for the $\mathrm{BC}_{2}$ and $\mathrm{G} \times \mathrm{M}$ progenies, flowering date was evaluated when $50 \%$ of the floral buds reached the full bloom stage. At INRA Bordeaux for the $\mathrm{J} \times \mathrm{F}$ and $\mathrm{R} \times \mathrm{L}$ progenies, and at the University of Bologna for the $\mathrm{L} \times \mathrm{B}$ progeny, flowering date was evaluated when $70 \%$ of the floral buds reached the full bloom stage. The two stages were evaluated for 2 years for the $\mathrm{J} \times \mathrm{F}$ progeny. For each genotype, the whole tree of one clone was observed every 1 or 2 days during the flowering period.

The fruit maturity date was evaluated in the five populations for 4 years $\left(\mathrm{J} \times \mathrm{F}, \mathrm{BC}_{2}\right.$ and $\left.\mathrm{G} \times \mathrm{M}\right)$ or 3 years $(\mathrm{L} \times \mathrm{B}$ and $\mathrm{R} \times \mathrm{L})$. The maturity for each tree was determined according to the softening of flesh.

Flowering and maturity dates were evaluated by a single person in each location and recorded as the number of days from 1 January to the date of flowering or maturity.

\section{Statistical analyses of phenotypic data}

Mean, minimum and maximum values of traits were calculated for the different years of evaluation. As only one replication per genotype was available, there was no control of micro-environmental variance. However, as many years of evaluation were available, a measure of between-year stability, which could be considered as a sort of broad-sense heritability $\left(\mathrm{H}_{\mathrm{BS}}\right)$, was estimated. $\mathrm{H}_{\mathrm{BS}}$ is defined as the ratio of genetic variance across phenotypic variance, or as a degree of confidence in the prediction of the genotypic values from the phenotypic values. It can be estimated by using replicated and randomly distributed genotypes. In our case, we considered the measures of each year as a random replication. Estimates were obtained from the analyses of variance based on the random linear model:

$$
Y_{\mathrm{ij}}=\mu+y_{\mathrm{i}}+g_{\mathrm{j}}+e_{\mathrm{ij}}
$$

where $Y_{\mathrm{ij}}$ is the phenotypic value of jth progeny in ith year; $\mu$ is the mean value of the trait; $y_{\mathrm{i}}$ is the random effect of the $i$ th year on the trait; $g_{\mathrm{j}}$ is the random genotypic effect of progeny $j$; and $e_{\mathrm{ij}}$ is the year $\times$ genotype interaction, that is residual of the model. Observations on a progeny are repeated measurements. A covariance structure was tested first, but no difference with residuals independence assumption was found.

$\mathrm{H}_{\mathrm{BS}}$ was estimated using the following equation:

$$
\mathrm{H}_{\mathrm{BS}}=\frac{s_{\mathrm{g}}^{2}}{s_{\mathrm{g}}^{2}+\frac{s^{2}}{n}}
$$

where $s_{\mathrm{g}}{ }^{2}=(\mathrm{MSg}-\mathrm{MSresidual}) n^{-1}$ is the genetic variance, MSg is the estimated mean square of genotypes, MSresidual is the estimated mean square of residual error, $s^{2}$ is a measure of variability due to genotype $\times$ year interaction, and $n$ is the number of years in the experiment.

\section{QTL analysis}

For the QTL analysis, linkage maps already available were used (Dirlewanger et al., 2004; Illa et al., 2009). All these maps include common markers and have already been compared (Illa et al., 2009), except the sweet cherry one. For $\mathrm{F}_{1}$ 
progenies, parental maps were analyzed separately using a pseudo testcross strategy (Grattapaglia and Sederoff, 1994).

QTL analysis was performed with MultiQTL V2.6 software (Haifa, Israel, 2005; http://www.multiQTL.com). Multiple interval mapping was used to detect QTLs (Kao et al., 1999). According to the principles of multiple interval mapping, a QTL with the highest effect is first found and it is taken as a cofactor to control the genetic background, whereas another QTL is searched in a different position. This procedure, iteratively repeated until no further QTL is found, takes into account effects of the QTLs present in other chromosomes. Therefore, the precision and power to detect QTLs are increased as compared with classical interval mapping approaches. Each year was analyzed independently for each trait in order to examine the stability of the QTL according to the year of evaluation. A joint analysis of the trait scores across years was also performed using the multiple environment option available in the MULTIQTL software, increasing the accuracy of the QTL detection and reducing the QTL confidence interval.

For the two types of analyses, year by year and multi-year analyses, QTL detection was performed following three steps. First, the single model was tested, that is, one QTL per LG using a permutation test and comparing hypotheses H1 (a single QTL present on the LG) and H0 (no QTL on the LG) Second, the two-linked QTL model was tested to compare the hypothesis H2 (two-linked QTLs on the LG) to H0. When the H2 hypothesis was significant, the third step was performed to compare the hypotheses $\mathrm{H} 2$ vs $\mathrm{H} 1$. This last step was performed to ensure that the two-linked QTL model fitted the data better than a single QTL model.

In all cases, chromosome-wide permutation tests with 1000 iterations were carried out to determine significance thresholds. A genome-wide type I error $\left(\alpha_{\mathrm{g}}\right)$ of $5 \%$ was chosen to declare statistically significant the presence of a QTL. Type I error at the chromosome level $\left(\alpha_{\mathrm{chr}}\right)$ was then calculated using the following relationship: $\alpha_{\mathrm{chr}}=1-\left\{1-\left[1-\left(1-\alpha_{\mathrm{g}}\right)^{1 / M}\right]\right\}^{m}$ where $M$ is the total number of markers used for the QTL detection on each map and $m$ the number of markers in the LG (Saintagne et al., 2004).

The s.d. for each QTL position was estimated by bootstrap analysis, with 1000 samplings.

The proportion of the phenotypic variation explained by the QTL (EV) was calculated as: $\mathrm{EV}=1 / 4\left(d^{2} / \alpha_{\mathrm{ph}}{ }^{2}\right)$ where $d$ is the estimated substitution effect of the QTL $(d=X(\mathrm{~A})-X(\mathrm{~B}), \mathrm{A}$ and $\mathrm{B}$ the two homozygote genotypes at the marker loci) and $\alpha_{\mathrm{ph}}$ the phenotypic variance of the trait. For the $F_{2}$ population the mid-parent value was also calculated: $h=X(\mathrm{H})-0.5[X(\mathrm{~A})+$ $X(\mathrm{~B})], \mathrm{H}$ being the heterozygous at the marker loci.

The graphical presentation of linkage maps and QTL was obtained using the MapChart software version 2.0 (Voorrips, 2002).

\section{In silico $\mathrm{CG}$ research}

Chromosomal regions for in silico CG analysis were initially selected based on the location of the QTLs associated with flowering and maturity dates. Predicted peach protein sequences and associated predicted gene functions derived from scaffolds underlying the major QTLs on LG4 and LG6 were downloaded from the Genome Database for Rosaceae (http:// www.rosaceae.org/node/355). For each CG, we mined the databases (essentially SWISS-PROT and TAIR), linked to the predicted gene function, for annotations, bibliographic data, phenotypic data of the mutations and any relevant information for their potential involvement in the control of the flowering and/or maturity dates. Data mining on the gene ontology terms associated with CGs was done using Blast2GO (Conesa et al., 2005). Predicted peach peptides were used for similarity search in a non-redundant genebank protein database with blastp algorithm with a minimum e-value $<10^{-6}$ before gene ontology mapping and annotation.

\section{RESULTS}

\section{Distribution of flowering and maturity dates}

Flowering date. The mean flowering date values and s.d. were calculated for the two peach progenies $\left(\mathrm{J} \times \mathrm{F}\right.$ and $\left.\mathrm{BC}_{2}\right)$, the apricot $\mathrm{G} \times \mathrm{M}$ and the sweet cherry $\mathrm{R} \times \mathrm{L}$ progenies (Table 1 ). They varied according to the year of evaluation, with an early bloom in 2008 (earliest for $\mathrm{J} \times \mathrm{F}, \mathrm{BC}_{2}$ and $\mathrm{R} \times \mathrm{L}$ ) and a late bloom in 2006 (latest for $\mathrm{J} \times \mathrm{F}, \mathrm{BC}_{2}, \mathrm{G} \times \mathrm{M}$ ) and 2010 (latest for $\mathrm{J} \times \mathrm{F}$ and $\mathrm{R} \times \mathrm{L}$ ), suggesting comparable climatic fluctuations, even if the progenies were not grown in the same region. The highest variation was observed for the peach progenies. For the $\mathrm{J} \times \mathrm{F}$ progeny, 22 days were observed between the mean flowering date in 2008 (3 March), and 2006 or 2010 (25 March). For the $\mathrm{BC}_{2}$ progeny, 20 days were observed between the mean flowering date in 2008 (1 March), and 2006 (21 March)

Within a progeny, the amplitude of the variation between the earliest and the latest flowering genotypes varied according to the year of evaluation. The highest amplitudes were observed for the peach $\mathrm{BC}_{2}$ in 2001 (26 days) and for the sweet cherry $\mathrm{R} \times \mathrm{L}$ in 2008 (25 days). The lowest amplitudes were observed for the peach $\mathrm{J} \times \mathrm{F}$ in 2005 and 2006 (5 days).

Maturity date. The mean maturity date values and s.d. were calculated for the five progenies (Table 1). Maturity for sweet cherry is the earliest among the Prunus and ranges from the beginning to the end of June with a mean maturity date at the middle of June. For apricot, the fruit maturity for the two progenies started at the beginning of June (4 June 2007) and finished at the middle of July (17 July 2006). For peach, maturity covers a large period, from the end of June to the end of September. The amplitude of the variation within a progeny is much higher for maturity date than for flowering date. The highest amplitude was observed for the peach progenies (93 days for the $\mathrm{BC}_{2}$ progeny in 2002 and 57 days for the $\mathrm{J} \times \mathrm{F}$ progeny in 2006). For apricot the amplitude ranged between 22 days to 30 according to the year of evaluation. The lowest amplitudes were observed for sweet cherry (15 days in 2006 to 27 days in 2009).

\section{Correlation between years and between traits}

Spearman correlation coefficients $(\rho)$ between years of evaluation for flowering and maturity dates and between these two traits are shown in Table 2. For each progeny, correlations between years for maturity date were much higher than those for flowering date. For flowering date, evaluations were performed following either 50 or $70 \%$ of the floral buds reaching the full bloom stage, according to the populations. For the peach $\mathrm{J} \times \mathrm{F}$ progeny, both measurements were done during 2 years. As correlations between the two measurements were very high ( 0.87 for both years), they were considered as similar in further analyses.

For all the progenies except the peach $\mathrm{BC}_{2}$, correlations between years for the flowering date were all highly significant $(P<0.001)$. The highest correlations were observed in the $\mathrm{R} \times \mathrm{L}$ sweet cherry progeny between the flowering date evaluations made in 2009 and 2010 $(\rho=0.87)$ and in the $\mathrm{J} \times \mathrm{F}$ peach progeny between evaluations made in 2007 and $2008(\rho=0.76)$. For the apricot $\mathrm{G} \times \mathrm{M}$, coefficient correlations between years were much lower and ranged from 0.34 to 0.47 .

For maturity date, the highest coefficient correlations between years were obtained for peach and reached 0.94 in the $\mathrm{BC}_{2}$ and 0.93 in the $\mathrm{J} \times \mathrm{F}$ progeny. The lowest coefficient correlations were observed for sweet cherry $(\rho=0.44)$. Flowering and maturity dates were not significantly correlated in the four analyzed populations evaluated, except in 2009 for the apricot $\mathrm{G} \times \mathrm{M}$ progeny $(\rho=0.32)$.

\section{Heritability of flowering and maturity dates}

For flowering date, $\mathrm{H}_{\mathrm{BS}}$ values ranged from 0.67 to 0.89 according to the progenies. The highest $\mathrm{H}_{\mathrm{BS}}$ estimates were obtained for peach 
Table 1 Mean values, s.d. and the value range for each progeny observed during the different years of evaluation of the flowering and maturity dates

\begin{tabular}{|c|c|c|c|c|c|c|c|c|c|c|}
\hline & 2001 & 2002 & 2003 & 2004 & 2005 & 2006 & 2007 & 2008 & 2009 & 2010 \\
\hline \multicolumn{11}{|l|}{ Flowering date } \\
\hline Mean \pm s.d. & - & $70.6 \pm 2.1$ & $76.0 \pm 2.8$ & $79.2 \pm 1.9$ & $80.8 \pm 1.0$ & $83.9 \pm 1.1$ & $67.9 \pm 2.3$ & $61.9 \pm 2.8$ & - & $83.9 \pm 1.6$ \\
\hline Minimum & - & 64.0 & 71.0 & 73.0 & 79.0 & 81.0 & 64.0 & 57.0 & - & 81.5 \\
\hline Maximum & - & 76.0 & 85.0 & 84.0 & 84.0 & 86.0 & 73.0 & 73.0 & - & 93.0 \\
\hline \multicolumn{11}{|l|}{$B C_{2}$} \\
\hline Mean \pm s.d. & $64.0 \pm 5.1$ & $65.8 \pm 2.9$ & - & - & $77.4 \pm 2.4$ & $79.6 \pm 3.3$ & $67.8 \pm 3.0$ & $59.8 \pm 3.3$ & $68.5 \pm 3.5$ & - \\
\hline Minimum & 48.0 & 56.0 & - & - & 68.0 & 66.0 & 58.0 & 41.0 & 59.0 & - \\
\hline Maximum & 74.0 & 72.0 & - & - & 83.0 & 85.0 & 75.0 & 63.0 & 72.0 & - \\
\hline \multicolumn{11}{|l|}{$G \times M$} \\
\hline Mean \pm s.d. & - & - & - & - & - & $76.4 \pm 3.1$ & $66.5 \pm 2.8$ & - & $65.0 \pm 2.2$ & - \\
\hline Minimum & - & - & - & - & - & 69.0 & 63.0 & - & 59.0 & - \\
\hline Maximum & - & - & - & - & - & 84.0 & 76.0 & - & 70.0 & - \\
\hline \multicolumn{11}{|l|}{$R \times L$} \\
\hline Mean \pm s.d. & - & - & - & - & - & $96.9 \pm 2.6$ & - & $94.7 \pm 3.7$ & $98.7 \pm 2.7$ & $102.5 \pm 1.6$ \\
\hline Minimum & - & - & - & - & - & 91.0 & - & 84.0 & 90.0 & 97.0 \\
\hline Maximum & - & - & - & - & - & 102.0 & - & 109.0 & 106.0 & 106.0 \\
\hline Maturity date & & & & & & & & & & \\
\hline$J \times F$ & & & & & & & & & & \\
\hline Mean \pm s.d. & - & $213.4 \pm 11.8$ & $211.2 \pm 13.2$ & - & - & $221.4 \pm 14.3$ & $215.2 \pm 14.0$ & - & - & - \\
\hline Minimum & - & 191.0 & 189.0 & - & - & 192.0 & 190.0 & - & - & - \\
\hline Maximum & - & 234.0 & 240.0 & - & - & 249.0 & 236.0 & - & - & - \\
\hline \multicolumn{11}{|l|}{$B C_{2}$} \\
\hline Mean \pm s.d. & $218.8 \pm 26.2$ & $219.9 \pm 24.1$ & - & - & $219.7 \pm 18.5$ & $219.1 \pm 21.0$ & - & - & - & - \\
\hline Minimum & 179.0 & 180.0 & - & - & 185.0 & 183.0 & - & - & - & - \\
\hline Maximum & 276.7 & 273.0 & - & - & 254.0 & 265.0 & - & - & - & - \\
\hline \multicolumn{11}{|l|}{$G \times M$} \\
\hline Mean \pm s.d. & - & - & - & - & - & $178.8 \pm 4.9$ & $173.4 \pm 5.2$ & $178.5 \pm 4.7$ & $178.5 \pm 6.3$ & - \\
\hline Minimum & - & - & - & - & - & 166.0 & 155.0 & 166.0 & 162.0 & - \\
\hline Maximum & - & - & - & - & - & 190.0 & 185.0 & 188.0 & 188.0 & - \\
\hline \multicolumn{11}{|l|}{$L \times B$} \\
\hline Mean \pm s.d. & - & - & - & - & - & $184.0 \pm 6.3$ & $167.4 \pm 6.0$ & $181.8 \pm 5.3$ & - & - \\
\hline Minimum & - & - & - & - & - & 170.0 & 157.0 & 172.0 & - & - \\
\hline Maximum & - & - & - & - & - & 198.0 & 179.0 & 196.0 & - & - \\
\hline \multicolumn{11}{|l|}{$R \times L$} \\
\hline Mean \pm s.d. & - & - & - & - & - & $163.5 \pm 4.6$ & - & $169.0 \pm 6.0$ & $167.0 \pm 5.8$ & - \\
\hline Minimum & - & - & - & - & - & $15 \overline{8} .0$ & - & 157.0 & 154.0 & - \\
\hline Maximum & - & - & - & - & - & 173.0 & - & 182.0 & 181.0 & - \\
\hline
\end{tabular}

( 0.89 for $\mathrm{J} \times \mathrm{F}, 0.88$ for $\mathrm{BC}_{2}$ ) and for sweet cherry (0.88), with almost identical values for these three populations, and the lowest for apricot $\mathrm{G} \times \mathrm{M}$ (0.67). In the case of peach, heritability values for populations $\mathrm{J} \times \mathrm{F}$ and $\mathrm{BC}_{2}$ are fully comparable as in both cases observations were available for a highly similar number of years ( 8 and 7 , respectively).

For maturity date, $\mathrm{H}_{\mathrm{BS}}$ ranged from 0.76 to 0.99 . The highest values were obtained for peach $\left(0.97\right.$ for $\mathrm{J} \times \mathrm{F}, 0.99$ for $\left.\mathrm{BC}_{2}\right)$ and the lowest for sweet cherry $(0.76$ for $\mathrm{R} \times \mathrm{L})$. Interestingly, $\mathrm{H}_{\mathrm{BS}}$ values were higher for the apricot progeny $\mathrm{L} \times \mathrm{B}(0.94)$ than for the apricot progeny $\mathrm{G} \times \mathrm{M}(0.86)$, despite a lower number of years of observation for the former population, 3 and 4 years respectively. Comparisons of $\mathrm{H}_{\mathrm{BS}}$ values between species are more pertinent for maturity date than for flowering date, as the number of observation years is more homogeneous for maturity date (ranging from 3 to 4) than for flowering date (ranging from 3 to 8 ).

\section{QTL analysis}

QTLs for flowering date. Results of QTL detection for flowering date are presented in Table 3 for the two peach progenies.

For the $\mathrm{J} \times \mathrm{F}$ progeny, QTLs were detected on all LGs, except for LG8 that has no segregating markers in this population (Dirlewanger et al., 2006). For all the 8 years, major QTLs were detected on two LGs, LG6 and LG7, with a maximum explained variation (EV) of
$35.3 \%$ and $23.9 \%$, respectively. QTLs with a smaller effect were also detected for all the 8 years on LG5 $(\mathrm{EV}=10 \%)$. On LG6, two QTLs were detected on the two extremities, with opposite effects (Table 3, Supplementary Figure S1). The confidence intervals were very small, especially for the year 2008, where each QTL covered $1 \mathrm{cM}$. On LG7, the EV of the QTL varied from $32.2 \%$ in 2003 to $8.1 \%$ in 2004 . In this LG, two QTLs were detected with opposite effects for the years 2002, 2003, 2006 and 2010 and only one for the years 2004, 2007 and 2008 corresponding to the QTL located on the lowest part of the group. When performing multi-year analysis, only the QTL at the bottom of LG7 was detected. QTLs detected on the other LGs were detected on a subset of the 8 years: LG1, LG2 and LG3 (6 years), LG4 (3 years). Their effects reached $12.2 \%$ of the EV (LG4 in 2002).

For the $\mathrm{BC}_{2}$ progeny, QTLs were also detected on all LGs, with the exception of LG8, those located on LG1, LG2 and LG6 having the highest effect (maximum $\mathrm{EV}=19.3,28.1$ and 30.1, respectively) (Table 3). Only the QTLs on LG1 were detected every year. During 4 years and for the multi-year analysis, two QTLs with the same effect (with the exception of 2001) were detected on LG1. The rest of the QTLs were detected on a subset of the 7 years: LG2 (5 years), LG6 (4 years), LG5 (3 years) and LG3, LG4 and LG7 (1 year). As observed for the $\mathrm{J} \times \mathrm{F}$ peach progeny, two QTLs with opposite effects were observed on LG6 but their mean positions were much closer and the 
Table 2 Spearman correlation coefficients between FD and Mat measured in the 5 progenies during several years

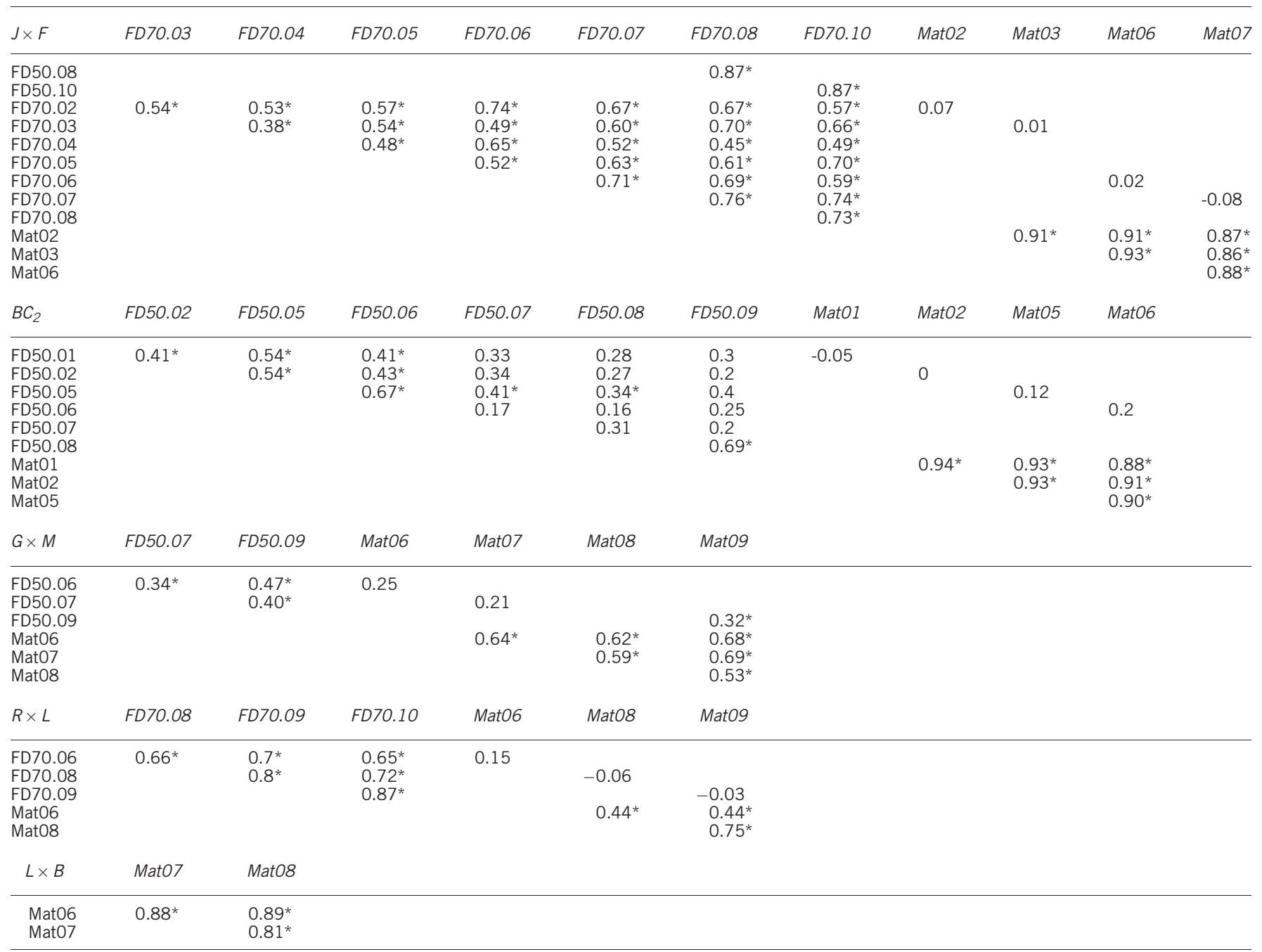

Abbreviations: FD, flowering date; MD, maturity date.

${ }^{*} P<0.001$.

QTL confidence intervals were much larger and partially overlapping (Supplementary Figure S1). For LGs 2 and 4, as for LG1, two-linked QTLs with the same effect were detected, either on a subset of years (LG2) or only with the multi-year analysis (LG4).

QTLs detected in the apricot $\mathrm{G} \times \mathrm{M}$ and in the sweet cherry $\mathrm{R} \times \mathrm{L}$ progenies are described in Table 4 . For each progeny they were detected separately in the two parents. In the apricot $G \times M$ the QTLs with the highest effect were located on LG4 only on 'Goldrich' $(\mathrm{EV}=25.1 \%)$ and were detected for all years (Supplementary Figure S2), as the QTL on LG7, which had a much smaller effect (Table 4). On 'Moniquí', QTLs were only detected in 2007 on LG2 and LG7. QTLs detected on LG3 on 'Moniquí' and on LG8 on 'Goldrich' were only detected by performing multi-year analysis.

For the sweet cherry $\mathrm{R} \times \mathrm{L}$, the QTL with the highest effect was detected on 'Regina' LG4 for the 4 years of evaluation (maximum $\mathrm{EV}=47.2 \%$ ) (Supplementary Figure S2; Table 4). QTL on 'Lapins' LG1 was also detected for the 4 years of evaluation but with a lower effect (maximum EV $=20.6 \%$ ). QTLs on LG2 (both on 'Regina' and 'Lapins') and LG6 (on 'Lapins') were only detected with the multi-year analysis. On 'Regina', two QTLs with opposite effects were detected on LG5 during 3 years $(2008,2009,2010)$ and on LG7 in 2008 .

QTL locations for flowering date were compared for the four progenies (Figure 1). QTLs were detected on LG2, LG3, LG4 and LG7 for peach, apricot and sweet cherry. The confidence intervals of the region covered by the QTLs were often wide except for LG4 where it covered a small area $(1 \mathrm{cM}$ in $\mathrm{R} \times \mathrm{L})$. QTLs on LG1, LG5 and LG6 were detected for peach and sweet cherry; and the one on LG8 was only detected in apricot.

QTLs for maturity date. The number of QTLs detected for maturity date was much lower than for the flowering date for all progenies (Table 5).

For all progenies, a QTL with major effect was detected on LG4 with a very high effect $(\mathrm{EV}=70.4 \%$ for the peach $\mathrm{J} \times \mathrm{F}, 18.4 \%$ for the peach $\mathrm{BC}_{2}, 37.6$ and $49.1 \%$ for the apricot 'Goldrich' and 'BO81604311', respectively; and 20.4\% for the sweet cherry 'Lapins'). If we consider the analyses year by year, this QTL appears as the one with the highest effect, detected for all years of evaluation. This QTL was mapped on the same chromosome position in peach and apricot, within a region including, or very close to, marker UPD97-402 
Table 3 QTLs controlling flowering date in the two peach progenies according to the year of evaluation

\begin{tabular}{lrrrrrrr}
\hline Year & $L G$ & $L(C M)$ & $C l(95 \%)$ & $L O D$ & $E V$ & $\mathrm{~d}$ & \multicolumn{1}{c}{$\mathrm{h}$} \\
\hline (a) $J \times F$ & & & & & & & \\
2002 & 1 & 36.4 & $(0 ; 70)$ & 9.3 & 8.7 & 0.9 & -0.1 \\
& & 84.0 & $(36 ; 103)$ & & & 0.0 & -0.6 \\
& 4 & 33.8 & $(14 ; 54)$ & 10.7 & 12.2 & 0.2 & -0.9 \\
& & 94.1 & $(31 ; 119)$ & & & 0.8 & 0.5 \\
& 5 & 7.3 & $(0 ; 23)$ & 9.2 & 12.9 & -0.2 & -0.9 \\
& & 20.1 & $(0 ; 58)$ & & & 1.2 & 1.3 \\
& 6 & 0.3 & $(0 ; 2)$ & 28.6 & 35.4 & 3.0 & -0.1 \\
& 7 & 67.4 & $(54 ; 81)$ & & & -1.4 & 0.6 \\
& 74.3 & $(35 ; 77)$ & 15.4 & 18.8 & -0.7 & -1.2 \\
& & 73.5 & $(63 ; 77)$ & & & 2.4 & 1.0
\end{tabular}

$\begin{array}{rrrrrrrr}2003 & 1 & 52.2 & (39 ; 65) & 7.9 & 10.5 & 2.4 & -0.5 \\ & 2 & 30.2 & (21 ; 39) & 4.2 & 4.1 & -1.2 & 0.6 \\ & 3 & 8.6 & (0 ; 19) & 10.2 & 8.5 & -0.7 & 0.0 \\ & & 21.9 & (0 ; 47) & & & 2.5 & 0.1 \\ & 5 & 8.5 & (0 ; 29) & 8.3 & 5.9 & 1.4 & 0.4 \\ & & 26.2 & (0 ; 80) & & & -1.0 & 0.3 \\ & 6 & 0.9 & (0 ; 7) & 19.9 & 16.3 & 2.5 & -0.1 \\ & & 75.8 & (73 ; 79) & & & -1.1 & -1.0 \\ & 7 & 9.6 & (0 ; 39) & 26.2 & 32.2 & -1.3 & 0.0 \\ & & 64.9 & (59 ; 70) & & & 4.2 & -0.6\end{array}$

2004

$\begin{array}{rrrrrrr}1 & 58.9 & (19 ; 98) & 3.9 & 7 & 1.2 & -0.3 \\ 4 & 49.0 & (18 ; 80) & 4.0 & 5.8 & -1.1 & 0.1 \\ 5 & 13.2 & (0 ; 41) & 5.6 & 7.7 & 1.4 & 0.1 \\ 6 & 3.7 & (0 ; 10) & 12.4 & \mathbf{2 7 . 3} & 2.4 & -1.0 \\ & 34.8 & (0 ; 74) & & & -1.2 & 0.5 \\ 7 & \mathbf{6 8 . 8} & (\mathbf{4 5 ; 8 2 )} & \mathbf{4} .7 & \mathbf{8 . 1} & \mathbf{1 . 4} & \mathbf{0 . 0}\end{array}$

2005

$\begin{array}{ll}1 & 56.6 \\ 2 & 25.3 \\ 3 & 40.3 \\ 5 & 34 \\ 6 & 72.5 \\ \mathbf{6} & \mathbf{7 0 . 4} \\ \mathbf{7} & 11.2 \\ & 61.2\end{array}$

2006

$\begin{array}{ll}2 & 31.2 \\ 3 & 25.9 \\ & 45.5 \\ \mathbf{5} & 10.7 \\ & \mathbf{4 3 . 4} \\ \mathbf{6} & 1.1 \\ \mathbf{7} & \mathbf{7 0 .} \\ & 17.3 \\ & \mathbf{5 8 . 9}\end{array}$

2007

$\begin{array}{rrrrrrr}2 & 28.7 & (14 ; 43) & 12.8 & 11.3 & -1.8 & -0.2 \\ & 51.2 & (28 ; 61) & & & 0.6 & 0.3 \\ 3 & 12.9 & (0 ; 31) & 9.2 & 5.2 & 0.6 & 0.3 \\ & 41.6 & (21 ; 47) & & & 1.0 & -0.1 \\ 5 & 31.9 & (0 ; 65) & 14.9 & 9.4 & 1.0 & 0.5 \\ & 54.9 & (32 ; 78) & & & 0.8 & -0.1 \\ 6 & 1.5 & (0 ; 4) & 41.6 & 35.8 & 2.9 & -1.5 \\ & 73.5 & (\mathbf{7 3} 74) & & & -1.9 & 0.2 \\ 7 & \mathbf{7 2 . 0} & (\mathbf{5 8 ; 8 2 )} & \mathbf{1 5 . 3} & \mathbf{2 3 . 8} & \mathbf{3 . 2} & -0.6\end{array}$

2008

$\begin{array}{rrrrrrr}1 & 39.7 & (11 ; 68) & 10.9 & 1.3 & 1.6 & -0.3 \\ & 72.8 & (32 ; 103) & & & -0.6 & -0.7 \\ 2 & 31.3 & (16 ; 46) & 10.0 & 7.6 & -2.2 & -0.4 \\ 3 & 12.0 & (0 ; 27) & 16.0 & 9.7 & 1.6 & 0.0 \\ & 39.1 & (16 ; 47) & & & 1.2 & -0.5 \\ 4 & 49.3 & (20 ; 79) & 5.3 & 4.6 & -0.3 & -1.2 \\ 5 & 10.1 & (0 ; 41) & 4.9 & 3.7 & 1.5 & -0.3 \\ 6 & 0.2 & (0 ; 1) & 39.2 & 29.4 & 3.5 & -1.0 \\ & 73.4 & (73 ; 74) & & & -2.6 & 0.1 \\ 7 & 69.7 & (62 ; 77) & 20.5 & 25.8 & 4.1 & -0.9\end{array}$

2010

$\begin{array}{rrrrrrr}1 & 54.7 & (46 ; 64) & 11.6 & 11.3 & 1.2 & -0.7 \\ 2 & 27.2 & (21 ; 33) & 16.6 & 11.8 & -1.5 & 0.1 \\ & 43.0 & (22 ; 61) & & & 0.2 & -0.2 \\ 3 & 5.6 & (0 ; 22) & 6.4 & 3.8 & 0.8 & 0.2 \\ 5 & 18.7 & (5 ; 32) & \mathbf{1 4 . 7} & 10.5 & 1.4 & -0.2 \\ 6 & 5.2 & (0 ; 22) & 21.0 & \mathbf{2 0 . 1} & 1.8 & -0.4 \\ & \mathbf{5 6 . 3} & (\mathbf{3 3} ; 80) & & & -0.8 & -0.2 \\ 7 & 8.7 & (0 ; 43) & \mathbf{2 6 . 9} & \mathbf{2 6 . 7} & -0.5 & -0.2 \\ & \mathbf{6 1 . 3} & (\mathbf{5 2 ; 7 1 )} & & & \mathbf{2 . 1} & -0.1\end{array}$

Table 3 (Continued)

\begin{tabular}{|c|c|c|c|c|c|c|c|}
\hline Year & $L G$ & $L(c M)$ & Cl (95\%) & $\angle O D$ & $E V$ & d & $\mathrm{h}$ \\
\hline \multirow{7}{*}{$\begin{array}{l}\text { (a) } J \times F \\
\text { Multi-year } \\
\text { analysis }\end{array}$} & 1 & 48.1 & $(37 ; 59)$ & 23.4 & 10.1 & 2.4 & -0.3 \\
\hline & $\begin{array}{l}2 \\
3\end{array}$ & $\begin{array}{l}27.4 \\
46.3\end{array}$ & $\begin{array}{l}(24 ; 31) \\
(39 \cdot 47)\end{array}$ & $\begin{array}{l}41.7 \\
31.9\end{array}$ & $\begin{array}{r}11.0 \\
7.4\end{array}$ & $\begin{array}{r}-1.6 \\
2.2\end{array}$ & $\begin{array}{l}-0.2 \\
-0.5\end{array}$ \\
\hline & 4 & 36.6 & (33;40) & 23.1 & 7.2 & 0.2 & -1.1 \\
\hline & 5 & $\begin{array}{l}11.4 \\
440\end{array}$ & $\begin{array}{l}(0 ; 26) \\
(8.80)\end{array}$ & 50.9 & 10.0 & $\begin{array}{l}1.4 \\
0.0\end{array}$ & $\begin{array}{l}0.1 \\
0.3\end{array}$ \\
\hline & 6 & 0.9 & $(0 ; 2)$ & 189.1 & 35.3 & 2.9 & -0.2 \\
\hline & & 73.3 & $(73 ; 74)$ & & & -1.5 & 0.5 \\
\hline & 7 & 63.8 & $(59 ; 68)$ & 95.8 & 23.9 & 4.0 & -0.7 \\
\hline Year & $L G$ & $L(c M)$ & $\mathrm{Cl}(95 \%)$ & $\angle O D$ & EV & d & \\
\hline
\end{tabular}

\begin{tabular}{|c|c|c|c|c|c|c|}
\hline $\begin{array}{l}\text { (b) } B C_{2} \\
2001\end{array}$ & 1 & $\begin{array}{l}28.3 \\
54.7 \\
54.4\end{array}$ & $\begin{array}{r}(0 ; 90) \\
(0 ; 128) \\
(22 ; 76)\end{array}$ & 9.2 & $\begin{array}{l}38.3 \\
17.7\end{array}$ & $\begin{array}{r}-5.5 \\
1.7 \\
-4.1\end{array}$ \\
\hline 2002 & $\begin{array}{l}2 \\
5 \\
6\end{array}$ & $\begin{array}{l}20.3 \\
91.7 \\
91.5 \\
67.3 \\
59.1\end{array}$ & $\begin{array}{r}(0 ; 71) \\
(32 ; 128) \\
(85 ; 92) \\
(56 ; 76) \\
(51 ; 67)\end{array}$ & $\begin{array}{l}6.5 \\
4.6 \\
6.1\end{array}$ & $\begin{array}{l}17.6 \\
16.1 \\
11.0\end{array}$ & $\begin{array}{r}-2.0 \\
-1.4 \\
-2.6 \\
-2.1 \\
2.2\end{array}$ \\
\hline 2005 & 1 & $\begin{array}{l}29.8 \\
77.0 \\
33.0 \\
85.2 \\
63.8\end{array}$ & $\begin{array}{r}(0 ; 101) \\
(0 ; 128) \\
(0 ; 88) \\
(69 ; 92) \\
(42 ; 76)\end{array}$ & 7.6 & 23.9 & $\begin{array}{l}-1.4 \\
-0.4 \\
-1.0 \\
-2.0 \\
-2.1\end{array}$ \\
\hline 2006 & $\begin{array}{l}2 \\
4\end{array}$ & $\begin{array}{r}42.4 \\
121.2 \\
79.5 \\
49.3\end{array}$ & $\begin{array}{r}(0 ; 114) \\
(78 ; 128) \\
(46 ; 92) \\
(38 ; 60)\end{array}$ & $\begin{array}{l}4.2 \\
7.5\end{array}$ & $\begin{array}{l}10.5 \\
23.4\end{array}$ & $\begin{array}{l}-1.3 \\
-2.6 \\
-2.4 \\
-3.7\end{array}$ \\
\hline 2007 & $\begin{array}{l}1 \\
3 \\
6\end{array}$ & $\begin{array}{l}20.9 \\
39.6 \\
54.7 \\
63.1\end{array}$ & $\begin{array}{r}(0 ; 86) \\
(26 . ; 53) \\
(29 ; 80) \\
(45 ; 79)\end{array}$ & $\begin{array}{r}3.7 \\
5.3 \\
11.3\end{array}$ & $\begin{array}{r}9.0 \\
21.6 \\
32.8\end{array}$ & $\begin{array}{r}-2.2 \\
3.8 \\
-5.9 \\
7.6\end{array}$ \\
\hline 2008 & $\begin{array}{l}1 \\
2\end{array}$ & $\begin{array}{r}107.4 \\
34.7 \\
66.8 \\
58.2 \\
69.2\end{array}$ & $\begin{array}{r}(90 ; 124) \\
(0 ; 73) \\
(32,92) \\
(40 ; 77) \\
(53 ; 82)\end{array}$ & $\begin{array}{r}5.8 \\
12.1 \\
9.6\end{array}$ & $\begin{array}{l}13.6 \\
36.4 \\
35.2\end{array}$ & $\begin{array}{r}-2.9 \\
-3.0 \\
-2.6 \\
6.5 \\
-5.4\end{array}$ \\
\hline 2009 & $\begin{array}{l}1 \\
2\end{array}$ & $\begin{array}{l}41.4 \\
23.2 \\
65.9 \\
51.8 \\
73.5 \\
11.7\end{array}$ & $\begin{array}{r}(0 ; 90) \\
(0 ; 59) \\
(18 ; 92) \\
(27 ; 77) \\
(50 ; 82) \\
(0 ; 36)\end{array}$ & $\begin{array}{l}3.9 \\
6.6\end{array}$ & $\begin{array}{l}24.9 \\
29.2 \\
\\
19.9\end{array}$ & $\begin{array}{r}-4.0 \\
-2.7 \\
-2.2 \\
3.6 \\
-3.1 \\
-2.7\end{array}$ \\
\hline $\begin{array}{l}\text { Multi-year } \\
\text { analysis }\end{array}$ & $\begin{array}{l}5 \\
6\end{array}$ & $\begin{array}{r}14.2 \\
107.3 \\
42.5 \\
84.1 \\
17.6 \\
42.3 \\
54.0 \\
61.2 \\
56.9 \\
65.4 \\
9.9\end{array}$ & $\begin{array}{r}(0 ; 54) \\
\\
(86 ; 128) \\
(4 ; 81) \\
(71 ; 92) \\
(0 ; 57) \\
(12 ; 73) \\
(38 ; 70) \\
(29 ; 76) \\
(32 ; 81) \\
(58 ; 73) \\
(0 ; 24)\end{array}$ & $\begin{array}{l}10.9 \\
21.3\end{array}$ & $\begin{array}{r}14.0 \\
16.9 \\
\\
8.6 \\
30.1\end{array}$ & $\begin{array}{r}-2.0 \\
-1.7 \\
-2.0 \\
-1.9 \\
-2.5 \\
-0.7 \\
-1.9 \\
-3.1 \\
-6.1 \\
8.2 \\
-0.9\end{array}$ \\
\hline
\end{tabular}

Abbreviations: $\mathrm{Cl}$, confidence interval; $\mathrm{d}$, difference $X(\mathrm{~A})-X(\mathrm{~B})$ according to the year of evaluation, where $A$ and $B$ are the two homozygotes at the marker loci; $E V$, variation explained by the QTL in percentage of the total variation explained; $h$, deviation from the mid-parent value, $X(\mathrm{H})-0.5(X(\mathrm{~A})+X(\mathrm{~B})) ; L$, distance from the beginning of the chromosome to the point of maximum LOD in the interval; LG, linkage group; LOD, logarithm of the odds ratio. QTLs detected every year are in bold and colored in gray. For multi-year analyses, only the values for $d$ and $h$ corresponding to the year with a highest EV (EVmax) are presented.

(Figure 2). In sweet cherry, the QTL was $15 \mathrm{cM}$ upstream of this marker. Additionally, QTLs controlling maturity date have been also identified on all other LGs but, differently from QTL on LG4, they are present in a subset of progenies: LG1 $(\mathrm{J} \times \mathrm{F}, \mathrm{R} \times \mathrm{L})$, LG2 $\left(\mathrm{BC}_{2}\right.$, $\mathrm{G} \times \mathrm{M}, \mathrm{L} \times \mathrm{B}), \mathrm{LG} 3\left(\mathrm{BC}_{2}, \mathrm{~L} \times \mathrm{B}\right), \mathrm{LG} 5(\mathrm{~J} \times \mathrm{F}, \mathrm{G} \times \mathrm{M}, \mathrm{R} \times \mathrm{L}), \mathrm{LG} 6$ 
Table 4 QTLs controlling flowering date in the apricot $(\mathbf{G} \times \mathbf{M})$ and sweet cherry $(\mathbf{R} \times \mathbf{L})$ according to the year of evaluation (see Table 3 for legend details)

\begin{tabular}{|c|c|c|c|c|c|c|}
\hline Year & $L G$ & $L(c M)$ & Cl (95\%) & $\angle O D$ & EV & d \\
\hline \multirow{3}{*}{$\begin{array}{l}\text { (a) } G \times M \\
2006\end{array}$} & & & & & & \\
\hline & G4 & 21.8 & $\begin{array}{r}(0 ; 53) \\
(46.531\end{array}$ & 10.4 & 24.3 & $\begin{array}{r}-0.3 \\
3.0\end{array}$ \\
\hline & G7 & 7.0 & $(0 ; 24)$ & 3.2 & 7.8 & -1.7 \\
\hline \multirow[t]{4}{*}{2007} & M2 & 60.7 & $(29 ; 81)$ & 3.5 & 9.0 & 1.7 \\
\hline & G4 & $\begin{array}{l}31.2 \\
50.2\end{array}$ & $\begin{array}{r}(6 ; 53) \\
(44.53)\end{array}$ & 9.4 & 24.2 & $\begin{array}{r}-1.8 \\
3.4\end{array}$ \\
\hline & G7 & 28.2 & $(0 ; 63)$ & 2.9 & 7.2 & -1.5 \\
\hline & M7 & 30.8 & $(4 ; 58)$ & 4.0 & 10.3 & 1.8 \\
\hline \multirow[t]{4}{*}{2009} & G2 & 28.5 & $\begin{array}{r}(5 ; 52) \\
(29.66)\end{array}$ & 5.4 & 8.7 & $\begin{array}{r}-0.5 \\
1.0\end{array}$ \\
\hline & G4 & 31.9 & $(8 ; 53)$ & 22.7 & 27.8 & -0 \\
\hline & & 50.0 & $(44 ; 53)$ & & & 1.8 \\
\hline & G7 & $\begin{array}{l}22.1 \\
35.8\end{array}$ & $\begin{array}{r}(0 ; 50) \\
(12 ; 60)\end{array}$ & 5.3 & 12.3 & $\begin{array}{r}0.6 \\
-1.4\end{array}$ \\
\hline \multirow[t]{9}{*}{ Multi-year analysis } & $L G$ & $L(c M)$ & Cl (95\%) & $\angle O D$ & Ev max & d \\
\hline & G2 & $\begin{array}{l}48.0 \\
608\end{array}$ & $\begin{array}{l}(26 ; 70) \\
(18.81)\end{array}$ & $\begin{array}{l}4.4 \\
4.4\end{array}$ & $\begin{array}{l}4.1 \\
7.2\end{array}$ & $\begin{array}{l}1.2 \\
1.3\end{array}$ \\
\hline & M3 & 36.4 & $(10 ; 63)$ & 8.7 & 11.7 & 0.2 \\
\hline & G4 & $\begin{array}{l}52.2 \\
33.8\end{array}$ & $\begin{array}{r}(3 / ; 64) \\
(8 ; 53)\end{array}$ & 32.4 & 22.0 & -1.8 \\
\hline & & 51.0 & $(48 ; 53)$ & & & 3.4 \\
\hline & G7 & 19.3 & $(0 ; 47)$ & 6.4 & 6.0 & -1.3 \\
\hline & M7 & 43.4 & $(14 ; 69)$ & 5.4 & 7.4 & 1.5 \\
\hline & G8 & 24.2 & $(19 ; 29)$ & 9.2 & 15.3 & -3.0 \\
\hline & & 33.1 & $(27 ; 39)$ & & & 3.5 \\
\hline Year & $L G$ & $L(c M)$ & Cl (95\%) & $\angle O D$ & EV & $d$ \\
\hline
\end{tabular}

\begin{tabular}{|c|c|c|c|c|c|c|}
\hline $\begin{array}{l}\text { (b) } R \times L \\
2006\end{array}$ & $\begin{array}{l}\text { L1b } \\
\text { R4 }\end{array}$ & $\begin{array}{l}40.9 \\
36.6\end{array}$ & $\begin{array}{l}(17 ; 47) \\
(23 ; 50)\end{array}$ & $\begin{array}{l}2.5 \\
7.7\end{array}$ & $\begin{array}{r}9.8 \\
24.3\end{array}$ & $\begin{array}{l}1.7 \\
2.6\end{array}$ \\
\hline \multirow[t]{4}{*}{2008} & $\begin{array}{l}\text { L1b } \\
\text { R3 }\end{array}$ & $\begin{array}{r}45.0 \\
6.2 \\
39.8\end{array}$ & $\begin{array}{r}(33 ; 47) \\
(0 ; 40) \\
(2 ; 77)\end{array}$ & $\begin{array}{l}3.3 \\
5.4\end{array}$ & $\begin{array}{l}10.1 \\
11.9\end{array}$ & $\begin{array}{r}2.4 \\
-1.6 \\
1.6\end{array}$ \\
\hline & R4 & 31.9 & $(22 ; 42)$ & 10.4 & 28.8 & 4.0 \\
\hline & R5 & $\begin{array}{l}39.8 \\
54.2\end{array}$ & $\begin{array}{r}(6 ; 73) \\
(21 ; 81)\end{array}$ & 9.3 & 39.0 & $\begin{array}{r}-4.2 \\
4.8\end{array}$ \\
\hline & R7 & $\begin{array}{r}7.3 \\
15.9\end{array}$ & $\begin{array}{r}(0 ; 30) \\
(0 ; 43)\end{array}$ & 4.8 & 11.7 & $\begin{array}{r}-3.3 \\
2.4\end{array}$ \\
\hline 2009 & $\begin{array}{l}\text { L1b } \\
\text { R4 } \\
\text { R5 }\end{array}$ & $\begin{array}{l}42.5 \\
33.2 \\
23.3 \\
55.7\end{array}$ & $\begin{array}{r}(21 ; 47) \\
(27 ; 39) \\
(0 ; 46) \\
(28 ; 81)\end{array}$ & $\begin{array}{r}2.7 \\
18.8 \\
8.4\end{array}$ & $\begin{array}{r}9.3 \\
46.2 \\
24.9\end{array}$ & $\begin{array}{r}1.7 \\
3.7 \\
-1.9 \\
1.7\end{array}$ \\
\hline 2010 & $\begin{array}{l}\text { L1b } \\
\text { R4 } \\
\text { R5 }\end{array}$ & $\begin{array}{l}39.8 \\
33.3 \\
17.6 \\
60.7\end{array}$ & $\begin{array}{r}(15 ; 47) \\
(30 ; 37) \\
(0 ; 37) \\
(44 ; 78)\end{array}$ & $\begin{array}{r}5.6 \\
15.7 \\
7.8\end{array}$ & $\begin{array}{l}17.5 \\
39.3 \\
20.9\end{array}$ & $\begin{array}{r}1.5 \\
2.0 \\
-1.1 \\
1.1\end{array}$ \\
\hline \multirow[t]{7}{*}{ Multi-year analysis } & $L G$ & $L(c M)$ & Cl (95\%) & $\angle O D$ & Ev max & d \\
\hline & $\begin{array}{l}\text { L1b } \\
\text { L2 }\end{array}$ & $\begin{array}{r}46.1 \\
8.9\end{array}$ & $\begin{array}{r}(40 ; 47) \\
(0 ; 19)\end{array}$ & $\begin{array}{l}\mathbf{2 7 . 0} \\
13.2\end{array}$ & $\begin{array}{l}20.6 \\
23.9\end{array}$ & $\begin{array}{r}4.0 \\
-4.0\end{array}$ \\
\hline & R2 & $\begin{array}{l}18.1 \\
26.7 \\
32.0\end{array}$ & $\begin{array}{l}(0 ; 40) \\
(0 ; 78) \\
(0 ; 85)\end{array}$ & 12.8 & 12.8 & $\begin{array}{r}2.8 \\
-3.1 \\
2.4\end{array}$ \\
\hline & L3b & 8.3 & $(5 ; 9)$ & 10.4 & 10.0 & 2.0 \\
\hline & R4 & 33.2 & $(33 ; 34)$ & 57.2 & 47.2 & 3.8 \\
\hline & R5 & $\begin{array}{l}33.0 \\
60.0\end{array}$ & $\begin{array}{l}(17 ; 49) \\
(48 ; 72)\end{array}$ & 24.1 & 26.1 & $\begin{array}{r}-3.5 \\
3.7\end{array}$ \\
\hline & $\begin{array}{l}\text { L6 } \\
\text { R7 }\end{array}$ & $\begin{array}{r}20.8 \\
1.7 \\
13.3\end{array}$ & $\begin{array}{l}(6 ; 36) \\
(0 ; 16) \\
(0 ; 40)\end{array}$ & $\begin{array}{r}7.6 \\
12.8\end{array}$ & $\begin{array}{l}10.1 \\
10.5\end{array}$ & $\begin{array}{r}-2.7 \\
-1.4 \\
1.0\end{array}$ \\
\hline
\end{tabular}

Abbreviations: G, Goldrich; L, Lapins; M, Moniqui; R, Regina. QTLs detected every year are in bold and colored in gray.

$(\mathrm{J} \times \mathrm{F}, \mathrm{G} \times \mathrm{M}, \mathrm{L} \times \mathrm{B}, \mathrm{R} \times \mathrm{L}), \mathrm{LG} 7(\mathrm{~J} \times \mathrm{F}, \mathrm{G} \times \mathrm{M}, \mathrm{L} \times \mathrm{B})$ and $\mathrm{LG} 8$ $\left(\mathrm{BC}_{2}, \mathrm{G} \times \mathrm{M}\right)$. Only two of these QTLs, on LG2 in $\mathrm{BC}_{2}$ and $\mathrm{L} \times \mathrm{B}$ and on LG6 in $\mathrm{J} \times \mathrm{F}$ and $\mathrm{R} \times \mathrm{L}$, explained more than $20 \%$ of variance
(Table 5). Six QTLs were only detected during 1 year and were not detected with the multi-year analysis: LG1 on J $\times$ F, LG5 on 'Moniquí, LG6 on 'BO81604311' and 'Lapins', LG7 on 'Goldrich' and LG8 on 'Moniquí.' On the other hand, the QTL detected on LG8 in the $\mathrm{BC}_{2}$ progeny was only detected with the multi-year analysis.

Comparison of the location of QTLs for flowering and maturity dates. QTLs for flowering and maturity dates were often located in the same regions (that is, they had overlapping confidence intervals), even though those two traits were not correlated, with the exception of the $\mathrm{G} \times \mathrm{M}$ population in 2009 (Tables 3, 4, 5). This was the case of LG2 for the peach $\mathrm{BC}_{2}$ and the apricots $\mathrm{G}$ and $\mathrm{M}$, of LG3 for the peach $\mathrm{BC}_{2}$, of LG4 for the peach $\mathrm{J} \times \mathrm{F}$ and $\mathrm{BC}_{2}$, of LG5 for $\mathrm{J} \times \mathrm{F}$, of LG6 for $\mathrm{J} \times \mathrm{F}$, and of $\mathrm{LG} 7$ for $\mathrm{J} \times \mathrm{F}$. The variation explained by the QTLs were either higher for flowering time or for maturity date, depending on the LGs and populations considered. For example, on LG4, the EV was much higher for the QTL for maturity date $(70.5 \%)$ than for the QTL for flowering date $(7.2 \%)$ on $\mathrm{J} \times \mathrm{F}$. On the other hand, on LG5, LG6 and LG7 the EV was higher for the QTL for flowering date than for the QTL for maturity date for $\mathrm{J} \times \mathrm{F}$. Finally, in $\mathrm{J} \times \mathrm{F}$ the EV was very high for both traits on LG6 (35.2\% for flowering date and $23.8 \%$ for maturity date).

In silico CG analysis. For flowering date, QTLs with the highest effect were detected on LG6 (for peach) and LG4 (for apricot and sweet cherry). For maturity date, a QTL with major effect was detected on LG4 for the three species (Figure 2). Consequently, we chose these two loci for further exploration by CG analysis, using anchored markers on the physical map within the loci. For the peach $\mathrm{J} \times \mathrm{F}$ and the apricot 'Goldrich', the confidence interval of the QTL for maturity date on LG4 covers $2 \mathrm{cM}$ (Table 5), around the UDP97-402 marker (Figure 2). In order to include both the QTLs of flowering and maturity date, $650 \mathrm{kbp}$ from $10347778 \mathrm{bp}$ of the scaffold 4 were screened. In this region, 102 genes were predicted on the peach ('Lovell') genome, from which $4.9 \%$ had no Blast hit in databases and $15.7 \%$ had Blast hits with unknown proteins. For the QTL controlling the flowering date on LG6, a confidence interval of $1 \mathrm{cM}$ was obtained for the peach $\mathrm{J} \times \mathrm{F}$, located at the bottom of LG6 (73-74 cM from the top, Table 3). To cover the region of the QTL, $700 \mathrm{kbp}$, starting from the MA014a marker, were screened (Figure 1, Supplementary Figure S1). In this region, 136 genes were predicted, from which $3.7 \%$ had no Blast hit in the databases and $18.4 \%$ had Blast hits with unknown proteins. Data mining on the two loci based on predicted protein function and their potential involvement in flowering and maturity date conducted to the selection of 17 CGs (4 on LG4 and 13 on LG6 ) (Table 6). From screening of the LG4 locus for genes potentially involved in the control of maturity date, we found a CG coding for a protein with high sequence similarity with the Arabidopsis ethyleneresponsive transcription factor 4 (ERF4). On the same locus, three CGs potentially involved in the control of flowering time, were detected. The first one codes for a protein very similar to the Arabidopsis CUP-SHAPED COTYLEDON 2 (CUC2). The second CG codes for a protein with high similarity with Arabidopsis Squamosa promoter-binding-like protein 5 (SPL5). The third CG on the LG4 locus was identified as SPA (SUPPRESSOR OF PHYA) 1-RELATED 3 protein (SPA3).

Screening of the LG6 locus allowed the detection of 13 CGs coding for proteins potentially involved in the control of flowering time. Auxin efflux carrier family protein, cell division control protein 2 homolog C, protein SCARECROW, glycosyltransferase QUASIMODO1, transcription factor MYB86, anaphase-promoting complex 
L1G
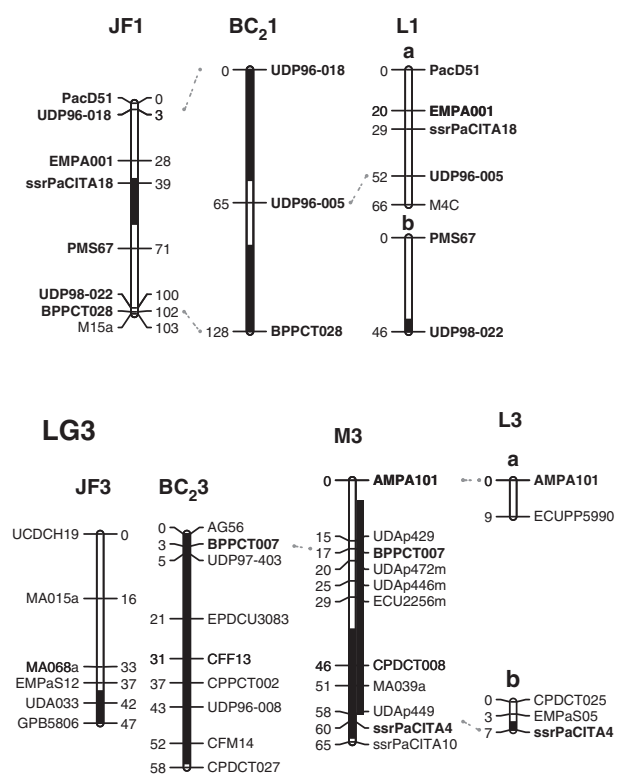

LG6

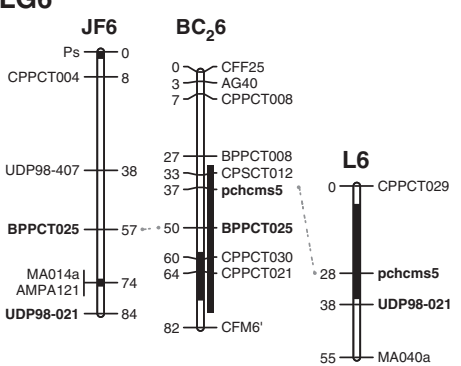

LG2
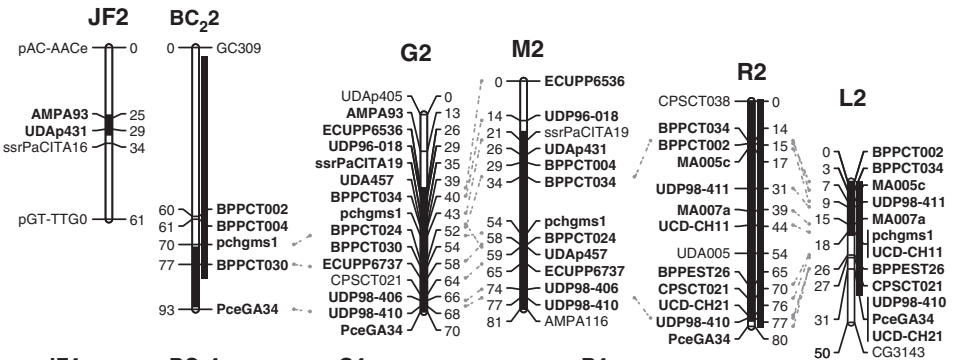

G4

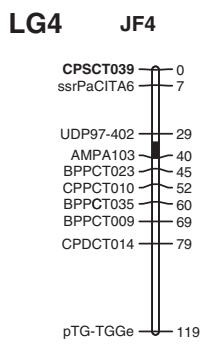

$\mathrm{BC}_{2} 4$

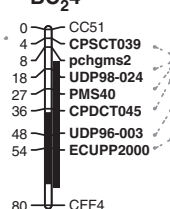

SSPPacita2

R4
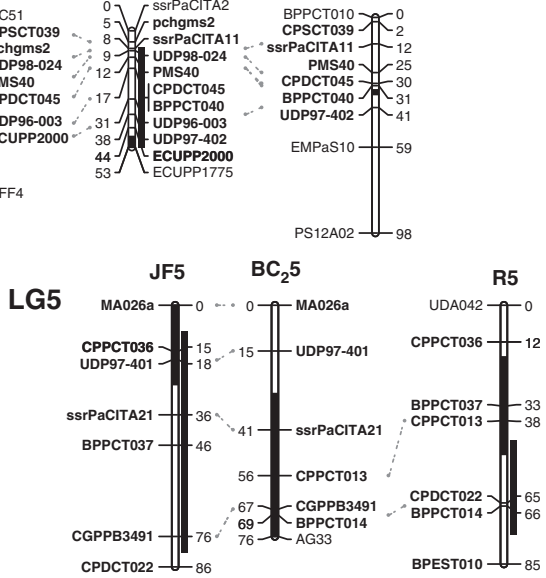

LG8

G8

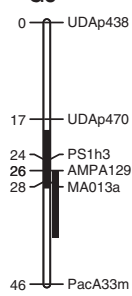

Figure 1 Location of QTLs controlling flowering date in four progenies: two peach $\left(\mathrm{J} \times \mathrm{F}, \mathrm{BC} \mathrm{C}_{2}\right)$, one apricot $\mathrm{G} \times \mathrm{M}$ and one sweet cherry $\mathrm{R} \times \mathrm{L}$. Only results using muti-year analyses from MultiQTL are indicated. Common markers between linkage groups are in bold, those common between adjacent linkage groups are linked by lines. Confidence intervals estimated on 1000 bootstrape are represented as solid bars.

subunit 11, agamous-like MADS-box protein AGL80 (X2) could be indirectly involved in flowering time regulation as they belong to developmental protein and cell division control protein families, respectively. Other CGs more directly implicated in the control of flowering time were identified: ubiquitin-protein ligase CIP8 (COP1 INTERACTING PROTEIN 8), PhyA (phytochrome A), transcription factor PIF3 (phytochrome-interacting factor 3) and FACT (Facilitates chromatin transcription complex) subunit SPT16 (X2).

Only the ERF4 is potentially implicated in the control of maturity date, the remaining are potentially involved in flowering date.

\section{DISCUSSION}

\section{Correlation between years and between traits}

For flowering date the highest correlations were observed between years for sweet cherry. This may be explained by the fact that in sweet cherry the highest amplitudes were observed between the earliest and the latest flowering genotypes. For the peach $\mathrm{J} \times \mathrm{F}$ the amplitude can be less than a week, then the evaluation is much more critical and yet high correlations were observed (Table 1). On the opposite, lower and more variable correlation coefficients were observed for the peach $\mathrm{BC}_{2}$ although the amplitude of the variation was high. This could be explained by two factors: less phenotypic data were available for $\mathrm{BC}_{2}$ and a higher interaction genotype $\times$ year (and hence genotype $\times$ climatic conditions) might exist for this progeny.

For maturity date in peach and apricot the amplitude of the variation within a progeny was much higher than for flowering date and this may explain a more reliable evaluation and then a higher correlation between years of evaluation.

Flowering and maturity dates were not significantly correlated in the four analyzed populations evaluated, except in 2009 for the apricot $\mathrm{G} \times \mathrm{M}$ progeny. This suggests that it will be possible to select late blooming varieties, with lower risk of spring frost, with early maturing fruits, usually corresponding to high economical value.

\section{Heritability values}

The present study highlighted that flowering and maturity dates were characterized by high heritability values. For flowering date, very similar values were obtained for the two peach progenies, despite the differences that were observed for the correlation coefficients. In sweet cherry, heritability values for flowering date were higher than for maturity date, as opposed to what was observed in peach and apricot. This result is in agreement to what was observed concerning correlation coefficient values. It also highlights specificities for each Prunus species: in peach and apricot the harvest period is far more 
Table 5 QTLs for maturity date according to the year of observation in peach, apricot and sweet cherry (see Table 3 for legend details)

\begin{tabular}{|c|c|c|c|c|c|c|c|}
\hline Year & $L G$ & $L(c M)$ & Cl (95\%) & $\angle O D$ & EV & $d$ & $\mathrm{~h}$ \\
\hline \multicolumn{8}{|l|}{ (a) $J \times F$} \\
\hline 2002 & $\begin{array}{l}4 \\
6\end{array}$ & $\begin{array}{l}39.0 \\
36.0 \\
56.1\end{array}$ & $\begin{array}{l}(35 ; 43) \\
(18 ; 54) \\
(38 ; 74)\end{array}$ & $\begin{array}{l}31.9 \\
24.1\end{array}$ & $\begin{array}{l}54.6 \\
30.2\end{array}$ & $\begin{array}{l}24.5 \\
15.9 \\
-7.7\end{array}$ & $\begin{array}{l}-1.5 \\
-6.6 \\
-1.0\end{array}$ \\
\hline & 7 & $\begin{array}{l}50.6 \\
69.9\end{array}$ & $\begin{array}{l}(19 ; 77) \\
(49 ; 77)\end{array}$ & 9.8 & 6.9 & $\begin{array}{r}-5.3 \\
0.0\end{array}$ & $\begin{array}{r}1.9 \\
-3.0\end{array}$ \\
\hline \multirow[t]{4}{*}{2003} & 4 & 38.7 & $(37 ; 41)$ & 53.7 & 70.0 & 30.6 & -0.8 \\
\hline & 5 & $\begin{array}{r}9.7 \\
69.4\end{array}$ & $\begin{array}{r}(0 ; 44) \\
(41 ; 86)\end{array}$ & 11.0 & 3.5 & $\begin{array}{l}3.7 \\
4.0\end{array}$ & $\begin{array}{l}1.9 \\
0.2\end{array}$ \\
\hline & 6 & $\begin{array}{l}33.9 \\
72.4\end{array}$ & $\begin{array}{l}(31 ; 37) \\
(62 ; 83)\end{array}$ & 32.6 & 15.7 & $\begin{array}{r}9.5 \\
-4.6\end{array}$ & $\begin{array}{l}-6.5 \\
-3.3\end{array}$ \\
\hline & 7 & $\begin{array}{l}51.3 \\
67.7\end{array}$ & $\begin{array}{l}(15 ; 77) \\
(50 ; 77)\end{array}$ & 7.8 & 3.0 & $\begin{array}{r}-4.0 \\
-4.3 \\
0.3\end{array}$ & $\begin{array}{r}1.6 \\
-0.7\end{array}$ \\
\hline \multirow[t]{5}{*}{2006} & 1 & $\begin{array}{l}16.1 \\
44.7\end{array}$ & $\begin{array}{l}(1 ; 31) \\
(0 ; 93)\end{array}$ & 13.8 & 2.7 & 3.1 & -1.8 \\
\hline & 4 & 38.8 & $(36 ; 41)$ & 61.7 & 72.8 & 33.9 & 0.8 \\
\hline & 5 & $\begin{array}{l}13.2 \\
406\end{array}$ & $\begin{array}{r}(1 ; 25) \\
(20.62)\end{array}$ & 13.5 & 2.1 & $\begin{array}{r}5.0 \\
-07\end{array}$ & $\begin{array}{l}0.2 \\
2.0\end{array}$ \\
\hline & 6 & $\begin{array}{l}34.0 \\
67.4\end{array}$ & $\begin{array}{l}(29 ; 39) \\
(58 ; 77)\end{array}$ & 40.9 & 16.3 & $\begin{array}{r}13.3 \\
-6.5\end{array}$ & $\begin{array}{r}-5.5 \\
1.0\end{array}$ \\
\hline & 7 & $\begin{array}{l}43.6 \\
68.1\end{array}$ & $\begin{array}{l}(17 ; 70) \\
(47 ; 77)\end{array}$ & 15.9 & 4.1 & $\begin{array}{r}-0.5 \\
-5.3 \\
0.2\end{array}$ & $\begin{array}{r}1.0 \\
2.5 \\
-0.8\end{array}$ \\
\hline 2007 & $\begin{array}{l}4 \\
6\end{array}$ & $\begin{array}{l}32.7 \\
27.1 \\
51.6\end{array}$ & $\begin{array}{r}(31 ; 34) \\
(7 ; 47) \\
(16 ; 84)\end{array}$ & $\begin{array}{l}62.3 \\
33.5\end{array}$ & $\begin{array}{l}69.4 \\
23.8\end{array}$ & $\begin{array}{r}32.6 \\
10.3 \\
-0.1\end{array}$ & $\begin{array}{l}-0.1 \\
-4.9 \\
-1.6\end{array}$ \\
\hline \multirow[t]{5}{*}{ Multi-year analysis } & $L G$ & $L(c M)$ & Cl (95\%) & $\angle O D$ & EVmax & $d$ & $\mathrm{~h}$ \\
\hline & 4 & & $(32 ; 34)$ & 170.8 & 70.4 & 34.3 & 0.3 \\
\hline & 5 & $\begin{array}{l}10.8 \\
62.7\end{array}$ & $\begin{array}{r}(0 ; 27) \\
(16 ; 86)\end{array}$ & 25.6 & 3.2 & $\begin{array}{l}2.0 \\
2.7\end{array}$ & $\begin{array}{l}1.1 \\
1.8\end{array}$ \\
\hline & 6 & $\begin{array}{l}33.9 \\
66.1\end{array}$ & $\begin{array}{l}(30 ; 38) \\
(48: 84)\end{array}$ & 103.0 & 23.8 & $\begin{array}{l}14.1 \\
-7.3\end{array}$ & $\begin{array}{l}-5.8 \\
-0.8\end{array}$ \\
\hline & 7 & $\begin{array}{l}55.4 \\
68.5\end{array}$ & $\begin{array}{l}(33 ; 77) \\
(49.77)\end{array}$ & 26.5 & 6.6 & $\begin{array}{r}-6.8 \\
0.7\end{array}$ & $\begin{array}{r}1.0 \\
-2.0\end{array}$ \\
\hline
\end{tabular}

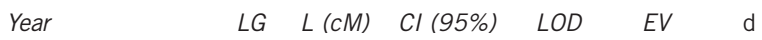

(b) $B C_{2}$

2001

2002

2005

2006

$\begin{array}{ccccccc}\text { Multi-year analysis } & L G & L(C M) & C l(95 \%) & \text { LOD } & \text { EVmax } & \mathrm{d} \\ & 2 & 34.2 & (16 ; 53) & 22.0 & 37.8 & 31.3 \\ & 71.8 & (41 ; 92) & & & -3.9 \\ & 3 & 29.5 & (11 ; 48) & 11.2 & 14.7 & 4.0 \\ & 42.7 & (28 ; 58) & & & 17.0 \\ & 4 & 25.3 & (0 ; 61) & 13.8 & 18.4 & -8.1 \\ & 48.0 & (13 ; 80) & & & 13.3 \\ & 8 & 17.8 & (6 ; 25) & 6.3 & 18.1 & 19.9\end{array}$

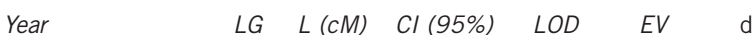

(c) $G \times M$

2006

$\begin{array}{lrrrlr}\text { G2 } & 34.2 & (9 ; 59) & 5.5 & 10.6 & -4.4 \\ & 46.7 & (23 ; 70) & & & 2.2 \\ \text { M2 } & 44.0 & (25 ; 63) & 3.7 & 11 & 3.2 \\ \text { G4 } & \mathbf{3 8 . 1} & (\mathbf{3 6 ; 4 0 )} & \mathbf{2 1 . 7} & \mathbf{3 6} & \mathbf{6 . 0} \\ \text { G6 } & 31.5 & (22 ; 41) & 8.8 & 13.8 & 3.7\end{array}$

2007

$\begin{array}{llllll}\text { M2 } & 48.3 & (28 ; 68) & 4.8 & 13.6 & 3.8\end{array}$

$\begin{array}{lllrll}\text { M2 } & 48.3 & (28 ; 68) & 4.8 & 13.6 & 3.8 \\ \text { G4 } & \mathbf{3 7 . 9} & (\mathbf{3 5} ; 40) & \mathbf{1 8 . 5} & \mathbf{3 5} & \mathbf{6 . 4}\end{array}$

Table 5 (Continued)

\begin{tabular}{|c|c|c|c|c|c|c|}
\hline Year & $L G$ & $L(c M)$ & Cl (95\%) & $\angle O D$ & EV & d \\
\hline & G7 & $\begin{array}{l}20.5 \\
43.3 \\
37.3\end{array}$ & $\begin{array}{r}(0 ; 44) \\
(10 ; 71) \\
(13 ; 61)\end{array}$ & 2.2 & 16.1 & $\begin{array}{r}3.8 \\
-1.4 \\
-1.8\end{array}$ \\
\hline 2008 & $\begin{array}{l}\text { G4 } \\
\text { M5 }\end{array}$ & $\begin{array}{r}41.1 \\
0.8 \\
17.8 \\
1.2 \\
10.7\end{array}$ & $\begin{array}{r}(32 ; 50) \\
(0 ; 8) \\
(9 ; 26) \\
(0 ; 13) \\
(0 ; 26)\end{array}$ & $\begin{array}{r}12.3 \\
6.3\end{array}$ & $\begin{array}{l}37.4 \\
27.9 \\
18.5\end{array}$ & $\begin{array}{r}5.9 \\
-4.8 \\
5.6 \\
-5.0 \\
5.8\end{array}$ \\
\hline 2009 & $\begin{array}{l}\text { G4 } \\
\text { G6 }\end{array}$ & $\begin{array}{l}41.5 \\
19.7\end{array}$ & $\begin{array}{r}(37 ; 45) \\
(1 ; 38)\end{array}$ & $\begin{array}{r}13.6 \\
8.3\end{array}$ & $\begin{array}{l}24.6 \\
13.1\end{array}$ & $\begin{array}{l}6.2 \\
4.5\end{array}$ \\
\hline Multi-year analysis & $L G$ & $L(c M)$ & Cl (95\%) & $\angle O D$ & EVmax & d \\
\hline & $\begin{array}{l}\text { G2 } \\
\text { M2 } \\
\text { G4 } \\
\text { G6 }\end{array}$ & $\begin{array}{l}59.8 \\
45.5 \\
38.5 \\
26.3\end{array}$ & $\begin{array}{l}(34 ; 70) \\
(36 ; 55) \\
(37 ; 39) \\
(11 ; 42)\end{array}$ & $\begin{array}{r}8.4 \\
11.0 \\
63.8 \\
19.3\end{array}$ & $\begin{array}{r}4.1 \\
12.7 \\
37.6 \\
13.1\end{array}$ & $\begin{array}{r}-2.5 \\
3.6 \\
6.2 \\
4.5\end{array}$ \\
\hline Year & $L G^{a}$ & $L(c M)$ & Cl (95\%) & $\angle O D$ & EV & d \\
\hline $\begin{array}{l}\text { (d) } R \times L \\
2006\end{array}$ & L6 & 33.3 & $(20 ; 40)$ & 3.6 & 47.5 & 6.8 \\
\hline 2008 & $\begin{array}{l}\text { L1a } \\
\text { L4 } \\
\text { L5 }\end{array}$ & $\begin{array}{r}49.2 \\
6.8 \\
72.2\end{array}$ & $\begin{array}{r}(39 ; 60) \\
(0 ; 15) \\
(27 ; 88)\end{array}$ & $\begin{array}{l}5.0 \\
8.1 \\
4.3\end{array}$ & $\begin{array}{l}12.1 \\
21.8 \\
13.2\end{array}$ & $\begin{array}{l}-4.0 \\
-5.5 \\
-4.2\end{array}$ \\
\hline 2009 & $\begin{array}{l}\text { L1a } \\
\text { L4 } \\
\text { L5 }\end{array}$ & $\begin{array}{r}44.9 \\
7.3 \\
37.1\end{array}$ & $\begin{array}{r}(35 ; 55) \\
(0 ; 19) \\
(10 ; 64)\end{array}$ & $\begin{array}{l}5.5 \\
3.1 \\
4.8\end{array}$ & $\begin{array}{r}15.5 \\
7.6 \\
12.7\end{array}$ & $\begin{array}{l}-4.4 \\
-3.1 \\
-4.0\end{array}$ \\
\hline \multirow[t]{2}{*}{ Multi-year analysis } & $L G$ & $L(c M)$ & $\mathrm{Cl}(95 \%)$ & $\angle O D$ & EVmax & $d$ \\
\hline & $\begin{array}{l}\text { L1a } \\
\text { L4 } \\
\text { L5 }\end{array}$ & $\begin{array}{r}47.1 \\
4.8 \\
68.7\end{array}$ & $\begin{array}{r}(37 ; 57) \\
(0 ; 13) \\
(16 ; 88)\end{array}$ & $\begin{array}{l}5.9 \\
8.9 \\
6.5\end{array}$ & $\begin{array}{l}10.7 \\
20.4 \\
13.3\end{array}$ & $\begin{array}{l}-3.9 \\
-5.4 \\
-4.3\end{array}$ \\
\hline Year & $L G^{b}$ & $L(c M)$ & Cl (95\%) & $\angle O D$ & EV & d \\
\hline
\end{tabular}

\begin{tabular}{|c|c|c|c|c|c|c|}
\hline (e) $L \times B$ & & & & & & \\
\hline 2006 & L2 & $\begin{array}{r}5.1 \\
22.9\end{array}$ & $\begin{array}{r}(0 ; 16) \\
(7 ; 39)\end{array}$ & 6.5 & 29.8 & $\begin{array}{r}3.7 \\
-7.4\end{array}$ \\
\hline & L4 & $\begin{array}{l}15.0 \\
51.9\end{array}$ & $\begin{array}{r}(0 ; 47) \\
(22 ; 64)\end{array}$ & 4.4 & 12.0 & $\begin{array}{l}1.8 \\
2.6\end{array}$ \\
\hline & B4 & 65.0 & $(58 ; 72)$ & 16.5 & 45.3 & 8.7 \\
\hline & L6 & $\begin{array}{l}10.3 \\
45.7\end{array}$ & $\begin{array}{r}(0 ; 24) \\
(17 ; 61)\end{array}$ & 6.7 & 19.2 & $\begin{array}{r}5.5 \\
-3.6\end{array}$ \\
\hline 2007 & L2 & $\begin{array}{r}4.7 \\
18.8\end{array}$ & $\begin{array}{r}(0 ; 12) \\
(7 ; 31)\end{array}$ & 8.0 & 37.5 & $\begin{array}{r}5.5 \\
-8.9\end{array}$ \\
\hline & B4 & 63.7 & $(56 ; 72)$ & 20.2 & 55.1 & 8.9 \\
\hline & L6 & 10.4 & $(0 ; 44)$ & 2.3 & 7.9 & 2.8 \\
\hline & B6 & 63.9 & $(35 ; 76)$ & 2.5 & 4.6 & 2.3 \\
\hline 2008 & L2 & 21.6 & $(14 ; 29)$ & 7.1 & 17.5 & -4.7 \\
\hline & L3 & 4.7 & $(0 ; 18)$ & 4.8 & 12.9 & -4.0 \\
\hline & & 34.3 & $(21 ; 37)$ & & & 2.2 \\
\hline & L4 & 30.5 & $\begin{array}{r}(8 ; 53) \\
(58.7 ?)\end{array}$ & $\begin{array}{l}4.0 \\
175\end{array}$ & $\begin{array}{l}11.9 \\
469\end{array}$ & 3.8 \\
\hline & L6 & 6.4 & $\begin{array}{r}(50 ; ; 2) \\
(0 ; 21)\end{array}$ & 6.7 & 17.4 & 5.1 \\
\hline & & 42.2 & $(10 ; 61)$ & & & \\
\hline & B7 & 80.8 & $(43 ; 95)$ & 3.1 & 7.3 & -2.9 \\
\hline Multi-year analysis & $L G$ & $L(c M)$ & Cl (95\%) & $\angle O D$ & EVmax & d \\
\hline & L2 & $\begin{array}{r}5.1 \\
19.7\end{array}$ & $\begin{array}{l}(0 ; 11) \\
(8 ; 31)\end{array}$ & 23.4 & 35.1 & $\begin{array}{r}4.9 \\
-8.3\end{array}$ \\
\hline & L3 & $\begin{array}{r}5.0 \\
355\end{array}$ & $(0 ; 18)$ & 9.1 & 12.3 & -3.8 \\
\hline & 14 & $\begin{array}{l}35.5 \\
33.4\end{array}$ & $\begin{array}{l}(273 /) \\
(19.48)\end{array}$ & 7.7 & 117 & 38 \\
\hline & B4 & 64.3 & $(61 ; 67)$ & 53.4 & 49.1 & 8.9 \\
\hline & L6 & 6.7 & $(0 ; 19)$ & 15.2 & 16.8 & 5.0 \\
\hline & B7 & $\begin{array}{l}49.7 \\
63.4\end{array}$ & $\begin{array}{r}(2 ; 61) \\
(30 ; 95)\end{array}$ & 11.4 & 16.8 & $\begin{array}{r}-3.2 \\
4.2\end{array}$ \\
\hline & & 86.6 & $(76 ; 95)$ & & -5.5 & \\
\hline
\end{tabular}

Abbreviations: B, BO 81604311; G, Goldrich; M, Moniqui; R, Regina.

QTLs detected every year are in bold and colored in gray.

aL: Lapins. 


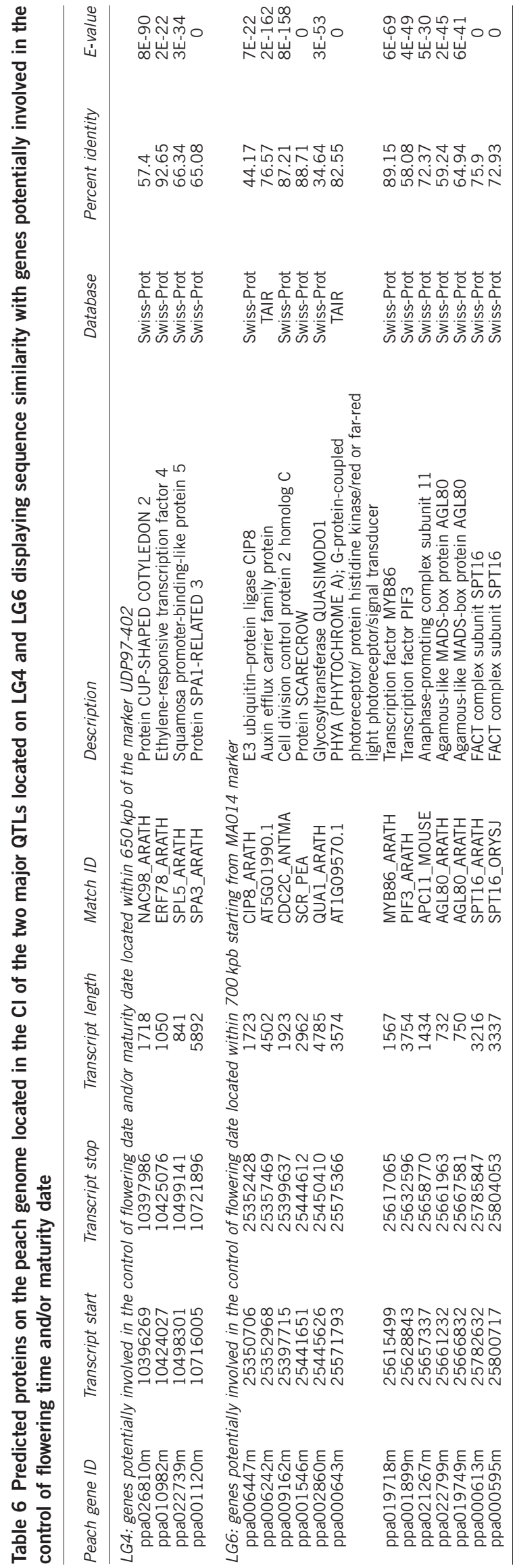

extended than the flowering period whereas in sweet cherry, depending on the progeny considered, both periods might be similar. Results also depend on the segregation for each trait within the studied progeny: for example in the case of sweet cherry, 'Regina' $\times$ 'Lapins' is a far more suitable cross to study flowering date than maturity date segregation: 'Lapins' is early flowering whereas 'Regina' is one of the latest flowering known commercial varieties; on the other hand, 'Lapins' and 'Regina' have intermediate and late maturity dates, respectively.

\section{QTL analyses}

The comparison of QTLs detected for flowering date in the four progenies highlights the huge complexity of this trait (Figure 1). This is in agreement with the hypothesis that many genes may be involved in the expression of this character. QTLs on LG2, LG3, LG4 and LG7 were detected for the three species confirming the high synteny level within the Prunus genus. All QTLs with high effect were detected each year of evaluation or for a majority of years, suggesting that they are not affected by climatic variations. On the opposite, several QTLs with low effect were detected only on a subset of the years of evaluation, suggesting a higher interaction with environmental conditions. Besides genotype $\times$ environment interactions, it is important to highlight QTL power detection issues. Indeed, the largest number of QTLs detected per year was observed in the peach progeny $\mathrm{J} \times \mathrm{F}$, which was the largest studied progeny, and which is an $\mathrm{F}_{2}$ progeny, thus better suited for QTL analyses than $\mathrm{BC}$ or $\mathrm{F}_{1}$ type progenies.

For flowering date, QTLs with high effect were detected on LG6 and LG4. On LG6, QTLs with major effect were detected in the two peach progenies. In each progeny, two QTLs with opposite effect were detected. Surprisingly, on the $\mathrm{BC}_{2}$, these QTLs were not detected in 2001, 2005 and 2006 but were detected with the highest effect in 2007 and 2008 and also with the multi-year analysis, suggesting a higher interaction with climatic conditions for this progeny. In the apricot 'Perfection', two QTLs controlling chilling requirements and bud break (Olukolu et al., 2009) were also detected on LG6 (Supplementary Figure S1). These results suggest that some of the genes involved in the control of the flowering date may be the same in different species and that chilling requirements and flowering date may be determined by the same or tightly linked genes. However, in our study no QTLs were detected on LG6 for the apricot $G \times M$, suggesting that QTL alleles might be identical for the parents of this progeny. On LG4, QTLs with major effect were detected in the sweet cherry 'Regina' and in the apricot 'Goldrich'. The location of this QTL in sweet cherry corresponds to the region of the major gene $L b$, detected in almond (Sánchez-Pérez et al., 2007) (Supplementary Figure S2).

QTLs were also detected on all the other LGs and their locations are consistent with previous studies. On LG1, QTLs for flowering date were detected in the two peach progenies and in the sweet cherry 'Lapins', in the same region as both QTLs for flowering date and chilling requirements detected in peach and the evergrowing locus (Fan et al., 2010). On LG5, two QTLs for flowering date were detected in the peach $\mathrm{J} \times \mathrm{F}$ and in the sweet cherry 'Regina'. The one on the upper part of the chromosome located in the same region as a QTL for flowering date with major effect detected in the apricot 'Z506-07 (Campoy et al., 2011). On LG7, QTLs for flowering date were detected for the four analyzed progenies, and were also detected on the same $L G$ in the peach $F_{2}$ population issued from the cross 'Contender' $\times$ 'Fla.92-2C' (Fan et al., 2010) and in the apricot $F_{1}$ population issued from 'Perfection' $\times$ A1740 (Olukolu et al., 2009). 


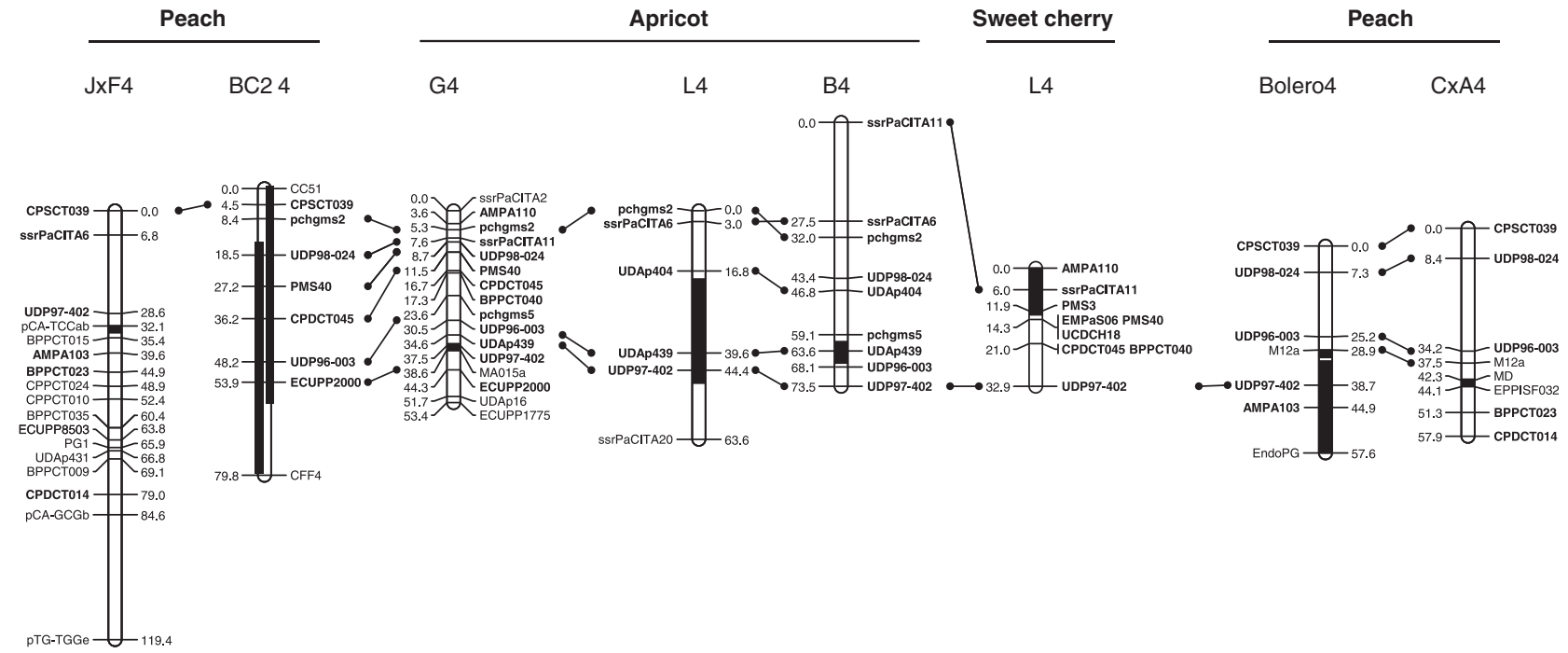

Figure 2 Location of QTLs controlling maturity date on LG4 detected in peach, apricot and sweet cherry by using the multiple environment function of MultiQTL. Common markers between linkage groups are in bold, those common between adjacent linkage groups are linked by lines. Solid bars indicate the confidence intervals estimated on 1000 bootstrap samples. QTLs controlling maturity date in the peach 'Bolero' and 'Contender $\times$ Ambra' F2 progeny detected in 2007 and 2008 are also indicated (Eduardo et al., 2011).

For maturity date, less QTLs with higher EVs were detected compared with flowering date. Hence, a QTL with major effect located on LG4 was detected in all progenies. The highest effect was detected for the peach $\mathrm{J} \times \mathrm{F}(\mathrm{EV}=70.4 \%)$. A QTL with a major effect was also reported to be located on LG4 in two peach progenies: an $\mathrm{F}_{1}$ from 'Bolero' and 'OroA' and an $\mathrm{F}_{2}$ derived from the cross between 'Contender' and 'Ambra' (C×A) (Eduardo et al., 2011) (Figure 2). The authors indicated that maturity date is a possible Mendelian trait. In the $\mathrm{C} \times \mathrm{A}$ progeny, the QTL explained $97.5 \%$ of the variation in 2007 and $97.7 \%$ in 2008 (Eduardo et al., 2011). QTLs controlling maturity date were also detected on LG4 in another peach progeny (Verde et al., 2002), and in almond (Sánchez-Pérez et al., 2007). All these data indicate that maturity date could be controlled by the same locus within the Prunus species and suggest that a selection for this trait should be efficient and rapidly integrated in breeding programs.

In the peach $\mathrm{BC}_{2}$ progeny no QTLs for maturity date were found in 2001. One possible explanation is that trees were 3 years old in 2001, still in their juvenile phase, and were unable to fully express their maturity potential. Thus, no maturity date could be recorded for 53 genotypes in 2001, reducing significantly QTL power detection. The number of missing data seems particularly well correlated with the number of QTL detected on $\mathrm{BC}_{2}$ for maturity date: the highest number was detected in 2002, with only 17 genotypes with missing data, followed by 2006 and 2005, with 31 and 43 genotypes with missing data, respectively. In the $\mathrm{R} \times \mathrm{L}$ progeny, only one QTL was detected during the first year of evaluation on LG6. As for $\mathrm{BC}_{2}$ in 2001, the $\mathrm{R} \times \mathrm{L}$ progeny was still in a juvenile phase in 2006. In 2008 and 2009, when trees had entered the adult phase, this QTL was not detected but three stable QTLs were identified on LGs 1, 4 and 5 .

Both for flowering and maturity dates, a significant interaction between QTL and year was detected. Indeed, considering all progenies, QTLs were detected during all years for flowering and maturity date only on 8 and 5 LGs, respectively. This highlights the need of conducting this type of study during a large number of years, due to between-year climatic variations. These variations may not affect significantly overall heritability values, as well as the detection of major QTLs, but they can be very important for the detection of minor QTLs. Thus, a precise understanding of these complex and critical phenological traits for fruit trees requires multi-year approaches. Another advantage of having numerous years of observation is that it helps to chose between the hypotheses of one or twolinked QTLs. Multi-year analyses conducted with MultiQTL software allow in some cases to reduce in a very significant way confidence intervals (for example for QTL detected on LG4 in sweet cherry 'Regina' parent, the confidence interval was reduced from $7-1 \mathrm{cM}$ ). Finally, this approach allowed as well the detection of QTLs that were not considered significant by doing single-year analysis.

\section{In silico CGs analysis}

In this study, the five populations were evaluated for many years (3-8) for flowering and maturity dates. The confidence intervals for some QTLs covered only 1 or $2 \mathrm{cM}$. Therefore, a CG analysis within these regions has been conducted.

ERF4 is a good CG for the control of maturity date. ERF family constitutes one of the largest transcription factor gene families in plants, containing a conserved DNA-binding domain (ERF domain (Nakano et al., 2006)). On the whole peach genome, 74 ERF genes were predicted including only one copy of ERF4. Most reported fruit ERFs have been shown to be induced with ripening or ethylene treatment, including plum, apple, tomato and kiwi (Tournier et al., 2003; Wang et al., 2007; El-Sharkawy et al., 2009; Yin et al., 2010). Subfamily VII (comprising ERF4) of ERF genes has been particularly associated with fruit ripening. The hypothesis that ERF4 controls the maturity date of climacteric fruits can explain that QTLs for maturity date in this locus, in peach and apricot, both climacteric fruits, had much higher effects than the one detected in sweet cherry, a non climacteric fruit. In order to confirm the role of ERF4 in the control of the maturity date, the sequence and the expression of this CG should be analyzed in a collection of genotypes with a large range of maturity.

On the same locus three CGs, potentially involved in the control of flowering time, were detected. CUC2 protein is thought to act in the development of embryos and flowers (Aida et al., 1997). The second, SPL5, is part of the SPL family and has overlapping functions 
with SPL3 and SPL4 in the regulation of vegetative phase change in Arabidopsis ( $\mathrm{Wu}$ and Poethig, 2006). The third one, SPA3, is a member of the SPA family that is essential for the inhibition of flowering under non-inductive short-day conditions (Laubinger and Hoecker, 2003). SPA regulates photoperiodic flowering by controlling the stability of the floral inducer CONSTANS (CO) and is part of the COP1/SPA E3 ubiquitin-protein ligase complex (Laubinger et al., 2006).

Thirteen CGs for the control of flowering time were detected on the LG6 locus. Eight of them could be indirectly involved in flowering time regulation as they belong to developmental protein family and cell division control protein family. The other five proteins could be more directly involved in the control of flowering date. CIP8 is a protein that binds to COP1 (Torii et al., 1999) similar to SPA proteins, and possess ubiquitin ligase activity (Hardtke et al., 2002). PhyA is a light-labile cytoplasmic red/far-red light photoreceptor involved in the regulation of photomorphogenesis. Phytochromes control flowering time in Arabidopsis (Schepens et al., 2004). Lightsignaling repressors SPA proteins contribute to COP1-mediated phyA degradation and a COP1/SPA1 protein complex is tightly associated with phyA ubiquitination activity (Saijo et al., 2008). Controlled degradation of the transcription factor PIF3 is a major regulatory step in light signaling. Accumulation of PIF3 in the nucleus in dark requires $\mathrm{COP} 1$, and red and far-red light induce rapid degradation of the PIF3 protein (Bauer et al., 2004). Mutant plants, with reduced amounts of FACT subunit SPT16, have a reduced expression of the floral repressor FLC and bloom early (Lolas et al., 2010).

In the present study, QTL analysis permitted the comparison of genomic regions influencing the flowering and fruit maturity dates in three Prunus species. The evaluation of these two traits being performed over many years, 8 years for one of the peach progenies, has allowed to reduce confidence intervals for the QTLs offering the possibility to explore two small regions having a high effect on these two traits by a CG approach. On LG4, the ERF4 gene can be proposed as a good candidate controlling the maturity date in peach and apricot, in agreement with the inheritance of this trait being determined by a major gene. For flowering date, 16 CGs were identified in the two regions. For most of them, they were reported to interact between them (SPA3, CIP8, phyA, PIF3), confirming that flowering date is a much more complex trait than maturity date. Next step will be to analyze how all these genes are regulated to understand how trees are capable to adapt to new climatic conditions and to design more efficient breeding strategies for the development of new cultivars adapted to them. A preliminary step will be to study the polymorphism within these CGs between the parents of the studied progenies, in order to test the QTL/CG colocalizations.

\section{DATA ARCHIVING}

Data have been deposited at Dryad: doi:10.5061/dryad.h29j4.

\section{CONFLICT OF INTEREST}

The authors declare no conflict of interest.

\section{ACKNOWLEDGEMENTS}

This work was partially supported by the ISAFRUIT Project funded by the European Commission-Food Quality and Safety of the 6th Framework Program of RTD (No. FP6-FOOD-CT-2006-016279).
Aida M, Ishida T, Fukaki H, Fujisawa H, Tasaka M (1997). Genes involved in organ separation in Arabidopsis: an analysis of the cup-shaped cotyledon mutant. Plant Cell 9: 841-857.

Alburquerque N, Garcia-Montiel F, Carrillo A, Burgos L (2008). Chilling and heat requirements of sweet cherry cultivars and the relationship between altitude and the probability of satisfying the chill requirements. Environ Exp Botany 64: 162-170.

Ballester J, Socias i Company R, Arús P, de Vicente MC (2001). Genetic mapping of a major gene delaying blooming time in almond. Plant Breed 120: 268-270.

Bauer D, Viczian A, Kircher S, Nobis T, Nitschke R, Kunkel T et al. (2004). Constitutive photomorphogenesis 1 and multiple photoreceptors control degradation of phytochrome interacting factor 3 , a transcription factor required for light signaling in Arabidopsis. Plant Cell 16: 1433-1445.

Campoy JA, Ruiz D, Egea J, Rees DJG, Celton JM, Martinez-Gomez P (2011). Inheritance of flowering time in apricot (Prunus armeniaca L.) and analysis of linked quantitative trait loci (QTLs) using simple sequence repeat (SSR) Markers. Plant Mol Biol Rep 29: 404-410.

Conesa A, Gotz S, Garcia-Gomez JM, Terol J, Talon M, Robles M (2005). Blast2GO: a universal tool for annotation, visualization and analysis in functional genomics research. Bioinformatics 21: 3674-3676.

Dirlewanger E, Cosson P, Boudehri K, Renaud C, Capdeville G, Tauzin Y et al. (2006). Development of a second-generation genetic linkage map for peach [Prunus persica (L.) Batsch] and characterization of morphological traits affecting flower and fruit. Tree Genet Genomes 3: 1-13.

Dirlewanger E, Graziano E, Joobeur T, Garriga-Caldere F, Cosson P, Howad W et al. (2004). Comparative mapping and marker-assisted selection in Rosaceae fruit crops. Proc Nat Acad Sci USA 101: 9891-9896.

Dirlewanger E, Moing A, Rothan C, Svanella L, Pronier V, Guye A et al. (1999). Mapping QTLs controlling fruit quality in peach (Prunus persica (L.) Batsch). Theor Appl Genet 98: 18-31.

Dondini L, Lain O, Geuna F, Banfi R, Gaiotti F, Tartarini S et al. (2007). Development of a new SSR-based linkage map in apricot and analysis of synteny with existing Prunus maps. Tree Genet Genomes 3: 239-249.

Eduardo I, Pacheco I, Chietera G, Bassi D, Pozzi C, Vecchietti A et al. (2011). QTL analysis of fruit quality traits in two peach intraspecific populations and importance of maturity date pleiotropic effect. Tree Genet Genomes 7: 323-335.

El-Sharkawy I, Sherif S, Mila I, Bouzayen M, Jayasankar S (2009). Molecular characterization of seven genes encoding ethylene-responsive transcriptional factors during plum fruit development and ripening. J Exp Bot 60: 907-922.

Fan S, Bielenberg DG, Zhebentyayeva TN, Reighard GL, Okie WR, Holland D et al. (2010). Mapping quantitative trait loci associated with chilling requirement, heat requirement and bloom date in peach (Prunus persica). New Phytol 185: 917-930.

Grattapaglia D, Sederoff R (1994). Genetic-linkage maps of Eucalyptus-Grandis and Eucalyptus -Urophylla using a pseudo-testcross-mapping strategy and RAPD markers. Genetics 137: 1121-1137.

Hardtke CS, Okamoto H, Stoop-Myer C, Deng XW (2002). Biochemical evidence for ubiquitin ligase activity of the Arabidopsis COP1 interacting protein 8 (CIP8). Plant J 30: 385-394.

Illa E, Lambert P, Quilot B, Audergon JM, Dirlewanger E, Howad W et al. (2009). Linkage map saturation, construction, and comparison in four populations of Prunus. J Horticult Sci Biotechno/ 84:Special Issue 168-175.

Joobeur T (1998). Construcción de un mapa de marcadores moleculares y análisis genético de caracteres agronómicos en Prunus. Universtat de Lleida: Spain, Lleida.

Kao CH, Zeng ZB, Teasdale RD (1999). Multiple interval mapping for quantitative trait loci. Genetics 152: 1203-1216.

Laubinger S, Hoecker U (2003). The SPA1-like proteins SPA3 and SPA4 repress photomorphogenesis in the light. Plant J 35: 373-385.

Laubinger S, Marchal V, Gentilhomme J, Wenkel S, Adrian J, Jang S et al. (2006). Arabidopsis SPA proteins regulate photoperiodic flowering and interact with the floral inducer CONSTANS to regulate its stability. (vol 133, pg 3213, 2006) Development 133: 4608.

Lolas IB, Himanen K, Gronlund JT, Lynggaard C, Houben A, Melzer M et al. (2010). The transcript elongation factor FACT affects Arabidopsis vegetative and reproductive development and genetically interacts with HUB1/2. Plant J 61: 686-697.

Nakano T, Suzuki K, Fujimura T, Shinshi H (2006). Genome-wide analysis of the ERF gene family in Arabidopsis and rice. Plant Physiol 140: 411-432.

Okie W, Blackburn B (2008). Interaction of chill and heat in peach flower bud dormancy. Hortscience 43: 1161-1161.

Olukolu BA, Trainin T, Fan S, Kole C, Bielenberg DG, Reighard GL et al. (2009). Genetic linkage mapping for molecular dissection of chilling requirement and budbreak in apricot (Prunus armeniaca L.). Genome 52: 819-828.

Quilot B, Wu BH, Kervella J, Genard M, Foulongne M, Moreau K (2004). QTL analysis of quality traits in an advanced backcross between Prunus persica cultivars and the wild relative species $P$. davidiana. Theor App/ Genet 109: 884-897.

Ruiz D, Campoy JA, Egea J (2007). Chilling and heat requirements of apricot cultivars for flowering. Environ Exp Bot 61: 254-263.

Saijo Y, Zhu D, Li J, Rubio V, Zhou Z, Shen Y et al. (2008). Arabidopsis COP1/SPA1 complex and FHY1/FHY3 associate with distinct phosphorylated forms of phytochrome A in balancing light signaling. Mol Cell 31: 607-613.

Saintagne C, Bodenes C, Barreneche T, Pot D, Plomion C, Kremer A (2004). Distribution of genomic regions differentiating oak species assessed by QTL detection. Heredity $\mathbf{9 2}$ 20-30. 
Sánchez-Pérez R, Howad W, Dicenta F, Arus P, Martinez-Gomez P (2007). Mapping major genes and quantitative trait loci controlling agronomic traits in almond. Plant Breed 126: 310-318.

Schepens I, Duek P, Fankhauser C (2004). Phytochrome-mediated light signalling in Arabidopsis. Curr Opin Plant Biol 7: 564-569.

Silva C, Garcia-Mas J, Sanchez AM, Arus P, Oliveira M (2005). Looking into flowering time in almond (Prunus dulcis (Mill) D. A. Webb): the candidate gene approach. Theor Appl Genet 110: 959-968.

Torii KU, Stoop-Myer CD, Okamoto H, Coleman JE, Matsui M, Deng XW (1999). The RING finger motif of photomorphogenic repressor COP1 specifically interacts with the RING-H2 motif of a novel Arabidopsis protein. J Biol Chem 274: 27674-27681.

Tournier B, Sanchez-Ballesta MT, Jones B, Pesquet E, Regad F, Latche A et al. (2003). New members of the tomato ERF family show specific expression pattern and diverse DNA-binding capacity to the GCC box element. Febs Letters 550: 149-154.
Verde I, Quarta R, Cedrola C, Dettori MT (2002). QTL analysis of agronomic traits in a BC1 peach population. Proceedings of the 5th International Peach Symposium, Acta Hortic 592: 291-297.

Voorrips RE (2002). MapChart: Software for the graphical presentation of linkage maps and QTLs. J Hered 93: 77-78.

Wang A, Tan D, Takahashi A, Li TZ, Harada T (2007). MdERFs, two ethylene-response factors involved in apple fruit ripening. J Exp Bot 58: 3743-3748.

Wang D, Karle R, lezzoni AF (2000). QTL analysis of flower and fruit traits in sour cherry. Theor Appl Genet 100: 535-544.

Wu G, Poethig RS (2006). Temporal regulation of shoot development in Arabidopsis thaliana by miR156 and its target SPL3. Development 133: 3539-3547.

Yin X-R, Allan AC, Chen K-S, Ferguson IB (2010). Kiwifruit EIL and ERF genes involved in regulating fruit ripening. Plant Physiol 153: 1280-1292.

Supplementary Information accompanies the paper on Heredity website (http://www.nature.com/hdy) 